\title{
Representación visual y simbólica de la militancia en las campañas electorales de Cristina F. de Kirchner (2007 y 2011) y Dilma Rousseff (2010 y 2014)
}

\author{
Dolores Rocca Rivarola
}

Nicole Marina Moscovich

\section{Introducción ${ }^{1}$}

Imágenes de multitudes agitando banderas y ovacionando, y de la candidata saludándolos, de modo colectivo o uno por uno, forman parte central de las campañas electorales en televisión. El contraste con la publicidad electoral audiovisual de las décadas previas es marcado. Luego de años de énfasis en un vínculo directo entre el líder y los votantes, las campañas audiovisuales de Cristina Fernández de Kirchner en 2011 y de Dilma Rousseff en 2014 exhiben y resaltan el papel intermediario de los militantes. ¿De qué modo y con qué tipo de recursos lo hacen? ¿Cómo interpretar esa estrategia de marketing electoral en las coyunturas políticas de ambos países? ¿De qué manera difiere de la esbozada en las campañas anteriores de ambas dirigentes (2007 en Argentina y 2010 en Brasil)?

Proponemos en este artículo analizar las cuatro campañas presidenciales de televisión de Cristina Fernández de Kirchner (en adelante CFK) y de Dilma Rousseff (2007 y 2011, y 2010 y 2014, respectivamente) con el objetivo de identificar e interpretar comparativamente el peso y las modalidades de visualización de la militancia oficialista como colectivo movilizado. Ello, en el marco de una investigación más amplia acerca de la transformación del vínculo militante en Argentina y Brasil desde los gobiernos de Néstor Kirchner y Luiz Inácio Lula da Silva².

Investigar el lugar asignado a la militancia como colectivo en las campañas electorales televisivas de ambas líderes es relevante por varias razones. En primer lugar, porque, aun en contextos de volatilidad electoral y fluctuación de la relación entre el electorado y los partidos políticos, la militancia no ha desaparecido (aunque sí se ha transformado). En segundo lugar, porque tanto durante el ciclo de gobiernos del PT en

\footnotetext{
${ }^{1}$ Agradecemos a las evaluadoras o evaluadores de la revista Opinião Pública por su cuidada revisión, que enriquecieron el artículo con sus preguntas y sugerencias.

2 Proyecto UBACYT 20020150200136BA (2016-2017) "La transformación del vínculo militante. Fenómenos de nostalgia, adaptación y militancia desde el Estado en organizaciones oficialistas en Argentina y Brasil desde 2003", dirigido por Dolores Rocca Rivarola, y radicado en el Instituto de Investigaciones Gino Germani, de la Universidad de Buenos Aires.
} 
Brasil como el de gobiernos del kirchnerismo en Argentina, las masas militantes oficialistas (es decir, que apoyaban activamente a estos gobiernos) asumieron una visibilidad y atención significativas. $Y$, en tercer lugar, porque, si bien ya hay en la literatura existente numerosos estudios sobre el lugar o dimensión que las siglas partidarias ocupan en las campañas electorales televisivas o gráficas en ambos países, el lugar visual de los colectivos militantes en las mismas ha sido un aspecto menos explorado.

El material empírico de este estudio se compone de dos tipos diferentes de piezas audiovisuales. Para Argentina, se recopilaron y analizaron 38 spots electorales, es decir, piezas cortas (de entre 50 segundos y tres minutos de duración): once para la campaña de 2007 y 27 para la de 2011 (ver listado en Anexos). Para Brasil, se relevó y examinó la totalidad de los programas electorales o "bloques" del denominado Horario Gratuito de Propaganda Electoral (HGPE) de 2010 y 2014 (para el primero y segundo turno de cada año). Se trata de piezas de mayor duración que los spots (un promedio de diez minutos). No existe en la campaña argentina un equivalente a ese tipo de programas ${ }^{3}$.

La decisión metodológica de tomar como material de consulta en Brasil los programas del HGPE y no los spots o "inserciones" breves (de entre 30 segundos y dos minutos), que, en apariencia, son similares a los argentinos, se basa en una serie de criterios y factores. En primer lugar, los propios spots aparecen incorporados, en muchos casos, como un fragmento o "jingle" dentro del programa del HGPE, con lo cual, al analizar éste último no se les excluye, sino que se amplía el espectro de observación.

En segundo lugar, para las campañas analizadas, el Tribunal Supremo Electoral (TSE) en Brasil era considerablemente restrictivo en cuanto al contenido de los spots. Por ejemplo, prohibía que el candidato filmara sus actos de campaña (comícios, en portugués) o cualquier otra actividad en la calle para exhibir en la TV (Borba, 2012). Solamente

\footnotetext{
3 Dado el contraste entre el tamaño de la muestra de propaganda electoral brasilera y la argentina (ver Anexos 1 y 2), cabe formular algunas aclaraciones sobre los criterios y condiciones de acceso a las piezas seleccionadas. Primero, el tamaño de ambos universos también es diferente. Es decir, mientras que la lógica del HGPE era la emisión de programas electorales diferentes y renovados poco menos que diariamente, en el caso argentino, la cantidad total de spots que circularon en la televisión durante la campaña fue mucho menor, habiendo más bien una repetición de los mismos spots en distintos horarios y emisoras. Por lo tanto, la dimensión menor de la muestra argentina refleja, en realidad, un universo total también menor de piezas publicitarias, al que se asemeja. Segundo, para el caso de las elecciones de 2007 en Argentina, en el que la muestra de spots es menor que en 2011, ello responde a dos circunstancias. Por un lado, a una limitación en el acceso, dado que, por entonces, con un desarrollo más incipiente de las redes sociales y la campaña online, menos material de campaña era subido a Internet que en los años posteriores. En 2011 y posteriormente, no sólo se compartió más material en la web, sino que, al haber una mayor regulación del espacio gratuito (y desaparecer los anuncios pagos por fuera del mismo), el acervo de spots quedó más centralizado luego de la campaña. Por otro lado, también la cantidad total de spots emitidos fue menor que en 2011, debido a que la campaña tuvo lugar bajo un marco legal diferente. Para 2011, como veremos, la ley de las PASO regulaba, prolongaba y dividía la campaña electoral televisiva en dos períodos, uno para las elecciones denominadas primarias (de definición de los candidatos para cada fuerza o frente político) y otro para las generales. Ello explica que, para 2011, los spots relevados fueran más numerosos, dado que efectivamente hubo una mayor cantidad. De todos modos, como lo exhiben las muestras relevadas, los spots compartían una línea temática, narrativa y estética similar a lo largo de toda la campaña (que fue diferente entre 2007 y 2011). Los spots fueron recogidos y encontrados en distintos sitios web, YouTube, en unos pocos casos, y en el archivo online del Observatorio de Campañas Electorales, creado por la Carrera de Ciencia Política de la UBA.
} 
permitía imágenes grabadas en estudio ${ }^{4}$. Esas limitaciones representan un obstáculo al comparar, entre Argentina y Brasil, el lugar simbólico de la militancia (en tanto colectivo, o miembros individuales, en tanto imagen, o con otros modos posibles de representación) en las campañas televisivas, dado que ya esa dimensión de representación estaría bloqueada de ser transmitida en Brasil. Esas limitaciones sobre los contenidos de los spots no existían, en cambio, para los programas del HGPE. Y finalmente, mientras que sólo unos pocos spots sueltos estaban disponibles online para consulta, fue posible una reconstrucción completa y exhaustiva del HGPE de ambas elecciones ${ }^{5}$.

A partir de una metodología de análisis de contenido cualitativo de la publicidad electoral audiovisual seleccionada (tanto de sus mensajes orales y escritos como de sus imágenes $)^{6}$, este artículo sintetizará a continuación los hallazgos. Las campañas televisivas de Dilma Rousseff y CFK en 2014 y 2011, respectivamente (orientadas a la reelección de ambas dirigentes), asignaron un mayor peso visual a la militancia y la movilización orgánica que las de 2010 y 2007. En ambos casos, lo hicieron a través de la exhibición de más imágenes de manifestaciones callejeras, actos de campaña (escenificados o no para su transmisión) y planos de militantes individuales o en grupos (e incluso, testimonios orales de los mismos). En Brasil, adicionalmente, se introdujo un segundo modo de representación de la militancia a través de una operación simbólica: la exaltación de la trayectoria de Dilma como militante juvenil durante la dictadura militar.

¿Cómo puede comprenderse ese contraste? Sin pretender revelar la estrategia interna exacta de las coordinaciones de campaña, el contexto puede echar algo de luz y sentido a ese despliegue visual del papel de intermediación de los militantes. En Argentina, cabría inscribir esta jerarquización visual de la militancia en la campaña electoral de 2011 en un proceso más general y duradero de asignación de una medular visibilidad a las bases militantes kirchneristas por parte del gobierno de CFK, especialmente a partir de la muerte de Néstor Kirchner en 2010 y del crecimiento sideral de la agrupación La Cámpora (y, en menor medida, de otras organizaciones juveniles). Ese proceso tendrá un clímax en el

\footnotetext{
${ }^{4}$ Específicamente no permite el uso de "grabaciones externas, montajes, trucos, computación gráfica, dibujos animados, efectos especiales, mensajes que ridiculicen o degraden" (Borba, 2012).

5 Facilitó el acceso a estos materiales la existencia de archivos de programas construidos y subidos a internet por equipos de investigación de Brasil, como el Canal Panke o también el canal del Núcleo de Estudos em Arte, Mídia e Política (Neamp), del Programa de Estudos Pós-Graduados em Ciências Sociais de la Pontifícia Universidade Católica de São Paulo (PUC-SP). Y, asimismo, se complementó ese acceso con un relevamiento propio en YouTube (consulta de programas subidos por el propio PT y demás actores de la coalición de Dilma).

${ }^{6}$ El análisis cualitativo de contenido desarrollado aquí se inscribe en una línea similar a los aportes de varias investigaciones, mencionadas más adelante en este trabajo, que han estudiado la campaña a través del rastreo e interpretación de los mensajes e imágenes del HGPE en Brasil. Para cada pieza examinada, se registró qué tipo de imágenes y en qué momentos hacían alusión de modo directo o indirecto al colectivo militante de sustentación de ambas líderes, o a la militancia en sí misma (como se verá más adelante a través de referencias a la propia trayectoria militancia de Dilma). También nos ha sido de utilidad el enfoque denominado "análisis de video interpretativo" (Knoblauch, Tuma y Schnettler, 2014). En vez de automatizar, codificar y reordenar segmentos de video de acuerdo con un esquema teórico previo de análisis de los datos, ese abordaje asume que las acciones registradas en video están orientadas por significados elaborados por los actores involucrados, que deberán ser considerados para la interpretación.
} 
fenómeno de los denominados "Patios Militantes" (2014-2015)7. La campaña de 2011 puede ser entendida, por tanto, como parte de un período en el que el kirchnerismo apeló recurrentemente a movilizar ese colectivo militante y lo ostentó como un logro distintivo de ese espacio político: el haber concitado compromisos leales, vehementes y emocionales ${ }^{8}$.

En Brasil, por su parte, en 2014, ya no era necesario, como sí en 2010, "presentar a Dilma en sociedad", o mostrarla, al igual que a CFK en 2007, como garantía de continuidad de una gestión anterior que gozaba de buena imagen (la de Lula y la de Néstor Kirchner). De igual manera, el escenario político también había cambiado. De modo similar a la muerte de Néstor Kirchner en Argentina, las manifestaciones populares de 2013 en distintas ciudades de Brasil constituyeron un episodio que debe ser tomado en cuenta a la hora de analizar y explicar el énfasis en los apoyos orgánicos de la militancia que se advierte en los programas del HGPE de 2014, tan sólo un año después del conflicto. Las denominadas "manifestaciones de junio" fueron protestas sin una orientación única y con consignas diversas, pero frente a las cuales la militancia del PT, de la CUT y de otras organizaciones oficialistas tuvieron cierta dificultad para participar ${ }^{9}$. En la campaña de 2014, la abundancia de alusiones a la militancia puede ser interpretada como un intento de apelar e identificarse con ese electorado juvenil y movilizado que se había involucrado en las jornadas de 2013, pero al margen del PT y de otras organizaciones oficialistas.

\section{Campañas electorales y audiovisuales en Argentina y Brasil desde la transición democrática: recorrido bibliográfico}

A la hora de describir el modelo de campaña política televisiva brasilero, Albuquerque (2005) propone un término alternativo al típico de advertising, utilizado en referencia al sistema estadounidense. Para el autor, la noción de "propaganda" parece más adecuada para dar cuenta de un sistema en el que el acceso a la televisión para la campaña electoral se hace, como veremos más adelante, bajo el patrocinio y la regulación del Estado. Desde la implementación de la Ley Electoral 26.571 en 2009, algo similar podría sostenerse para el caso argentino. Limeira y Maia (2010) se refieren a la propaganda electoral como un tipo de comunicación política de persuasión usada por los partidos que incluye recursos psicológicos e informativos.

\footnotetext{
7 Para una reflexión acerca de los Patios Militantes, actos posteriores a las transmisiones de la Cadena Nacional en los que CFK se dirigía a una multitud de activistas reunidos en los patios de la Casa Rosada, y de la ritualidad kirchnerista, ver Rocca Rivarola (2017a).

${ }^{8}$ La exaltación pública por parte del kirchnerismo de sus propias bases militantes ha sido abordada también por otros trabajos. Quirós (2014) afirma, por ejemplo, que el kirchnerismo desde el Estado hizo de la militancia un valor y consigna propio. Vázquez (2013) estudió la construcción kirchnerista de la juventud como causa que generaba adhesiones y participación política. Y en el discurso kirchnerista, Montero (2009) identifica una reivindicación de la militancia juvenil de los años setenta y la configuración de un ethos militante transgresor.

9 Para un análisis comparativo de esas protestas y las de 2015/2016 en Brasil, ver Rocca Rivarola (2016).
} 
Entre las numerosas y amplias discusiones acerca de las campañas y propaganda electoral, la cuestión de la mediatización de la política (Verón, 1998 ${ }^{10}$; Sartori, 2003; Ribeiro, 2004 y otros) se vuelve transversal. Se ha argumentado, por otro lado, que la acción política en el espacio público democrático siempre construye un régimen de visibilidad, con o sin la mediatización de la televisión (Cingolani y Fernández, 2010). Es decir, que la puesta en escena política en el escenario público siempre asume una forma de espectáculo, y lo que varía con la irrupción de la televisión sería la escala del mismo (Verón, 2002).

En el marco de esa mediatización, la creciente importancia de los spots propagandísticos de televisión ha sido más desarrollada, y también con anterioridad, desde la literatura estadounidense ${ }^{11}$ (Kaid et al., 1993; Johnston y Kaid, 2002; Brader, 2005). En Brasil y Argentina, sobresalen, de todos modos, algunos trabajos sobre el uso que se ha hecho de la publicidad electoral televisiva, como Borba (2008 y 2012), Waisbord (1993), y García Beaudoux y D'Adamo (2006), además de otros centrados en campañas electorales específicas, y que serán mencionados más adelante en esta sección.

De igual manera, cada vez más trabajos han puesto atención en las campañas online, la creación y difusión de sitios web de los candidatos, y la actuación de éstos y de su base militante en las redes sociales (Facebook, Twitter etc.). Marques y Sampaio (2011) consideran, para el caso brasilero, la transformación de la comunicación política digital (aunque no total, dado que suponen que las dimensiones específicas del juego político son algo refractarias a modificaciones bruscas, incluso al avance tecnológico), especialmente hacia las elecciones de $2010^{12}$, y la creciente importancia de la campaña online (aunque con un menor uso por parte de los candidatos luego más votados ${ }^{13}$ ). Analizando los sitios web de la campaña de 2014, Massuchin y Tavares (2016) afirman que entre 2002 y 2010 hubo un "bajo uso de las potencialidades de la red" (p. 13). Y ambos trabajos mencionados sostienen que Internet fue utilizada durante años también como espacio de transmisión de contenidos que no eran permitidos por el Tribunal Superior Electoral (TSE) en la campaña televisiva (programas del HGPE, spots etc.), hasta que la red empezó a ser más monitoreada por ese organismo. Para Argentina, el uso de Twitter por parte de CFK en 2011, y su interacción con la campaña televisiva, ha sido motivo de distintos análisis (Slimovich, 2016; Ventura, 2016), o en torno, por ejemplo, a la creación de un vínculo

\footnotetext{
10 Para Verón, la mediatización de la política interactúa con la crisis de legitimidad de la política organizada.

11 La propia historia del marketing político en EEUU es más larga que en América Latina, usándose ya spots propagandísticos en la década del '50 y debates televisivos entre candidatos en los '60 (Oliveira, 2013).

12 Un ejemplo de ello se ve en la campaña de Dilma. En su tesis sobre la militancia juvenil del PT, Marques (2016) menciona como un vehículo central de comunicación de las actividades de campaña de la juventud partidaria el portal de Internet "Galera da Dilma" [la gente de Dilma], interactivo, con agendas de actividades, encuestas, descarga y subida de videos por parte del público. Y para esa misma elección, la JPT lanzaría la campaña "seja um petista 2.0", como proyecto de formación de jóvenes militantes online. Es en el HGPE de 2014 cuando se hará más notable la interacción entre el programa de campaña televisivo y las redes sociales, advirtiéndose en casi todos los programas alguna referencia a un link o Facebook o Twitter al que poder ingresar o subir fotos con Dilma.

13 Bachini (2013) sostiene algo similar para la campaña de 2010.
} 
virtual o imaginario de proximidad o de política directa en sus tweets (Annunziata, 2012). De todos modos, sin omitir la importancia creciente de las campañas online y de la militancia virtual, este artículo se dedica a analizar el lugar visual y simbólico de la militancia en la campaña televisiva.

Y tanto la centralidad de la televisión como los nuevos usos tecnológicos pueden ser entendidos como elementos de una transformación más general de las campañas electorales. Norris (2001, 2008) define, por ejemplo, las campañas electorales occidentales a través de tres momentos: un primer momento definido como "premoderno", hasta 1950 (con formas más directas de comunicación entre electores y candidatos, en las que los militantes y voluntarios eran responsables por la campaña y por la llegada a los votantes, con una fuerte identificación partidaria); una segunda fase "moderna", de 1950 a 1980, inaugurando un proceso de profesionalización de la campaña (con la llegada de la televisión, con terceros coordinando una estrategia nacional, realización de encuestas de opinión etc.) y una tercera etapa, desde mediados de la década del ' 90 , caracterizada por una profesionalización total, que alcanza a todas las actividades de campaña. La autora advierte allí una segmentación de mensajes, estrategias diferenciadas entre la televisión y las nuevas tecnologías para la interacción partidos-medios-público, y un incremento sustantivo de los gastos de campaña, aumentando la contratación de personal por sobre la utilización de militantes ${ }^{14}$.

Para Brasil, Albuquerque (1999) ha identificado ese proceso de profesionalización recién hacia el final de la década del '80, luego de la redemocratización (1985). Y Ribeiro (2008), para el caso específico del PT, lo describe como un cambio de un modelo de campañas trabajo-intensivo a otro capital-intensivo. Dias (2013) delinea el fenómeno de profesionalización en Brasil como la creciente participación de agentes no partidarios en la formulación y ejecución de la campaña, marginando del proceso a la burocracia partidaria, y privilegiando criterios de marketing por encima de los político-partidarios.

Para el caso argentino, Muraro (1990), Waisbord (1993) y Soprano (2003) también advierten una tendencia a partir de la transición democrática hacia la profesionalización de las campañas electorales y la planificación y ejecución de las mismas por parte de especialistas en marketing político. Muraro adiciona, por su parte, elementos como la caída del rol de la militancia, la concepción de la publicidad como agente de reclutamiento y de socialización, e incluso la transformación del candidato en un producto de marketing político, con campañas sumamente personalizadas.

Ese fenómeno de personalización de las campañas, o hipervalorización de los liderazgos individuales y énfasis en sus atributos personales por sobre sus organizaciones o colectivos de pertenencia, por su parte, ha recibido bastante atención, tanto a nivel

\footnotetext{
${ }^{14}$ Aunque los tiempos de la periodización pueden variar significativamente a la hora de pensar el contexto latinoamericano, los testimonios de entrevistados del PT y otras organizaciones afines describían de modo recurrente y críticamente un proceso de profesionalización de las campañas del PT hacia fines de la década del ' 90 en Brasil y, sobre todo, desde 2002 (Rocca Rivarola, 2017b).
} 
general (Manin, 1992; Gunther y Diamond, 2003), como en torno a los casos argentino (D'Alessandro, 2004; García Beaudoux y D'Adamo, 2004; Cheresky, 2007) y brasilero (Ângelo, 2012; Telles y Pires, 2013; Nicolau, 2015).

Por otro lado, un considerable número de investigaciones y ensayos han abordado el análisis de las diferentes campañas presidenciales -especialmente en su dimensión televisiva- del período previo al recorte temporal de este artículo en Argentina y Brasil.

A modo de ejemplo, la campaña de 1983 en Argentina ha sido interpretada como un punto de inflexión o bisagra entre la vieja y la nueva era de la política electoral (Pousadela y Cheresky, 2004; Vommaro, 2006), con reafiliaciones masivas a los partidos, multitudinarios actos públicos y ritos partidarios, pero a la vez la consolidación de una nueva incertidumbre político-electoral generada por la aparición masiva de la figura de los votantes "indecisos" e "independientes", que hacían prever tendencias de volatilidad electoral en los comicios por venir. Las propias actividades de campaña ya experimentarían una mutación hacia las elecciones de 1989, con caravanas y recorridas suplantando a las masivas manifestaciones populares de 1983 (Palermo y Novaro, 1996), y haciendo énfasis en la proximidad y en los atributos individuales carismáticos del candidato (Arias, 1996). La particular campaña presidencial de 2003, celebrada poco más de un año después del estallido de la crisis de 2001 y en un contexto de notable fragmentación al interior de los partidos tradicionales, exhibiría, en el caso de Néstor Kirchner, una estrategia múltiple: asociarlo a dirigentes locales y redes territoriales peronistas del conurbano bonaerense (afines a su patrocinador, Eduardo Duhalde, entonces presidente interino); mostrar en los spots una eventual continuidad con la gestión económica; y lograr un enfrentamiento de lógica binaria contra Carlos Menem (Rocca Rivarola, 2011). Y las distintas campañas televisivas de 2003 fueron modestas, poco sofisticadas y relativamente pobres en recursos de marketing político (García Beaudoux y D'Adamo, 2006).

También en torno al período previo a nuestro recorte temporal, en Brasil algunos trabajos han estudiado, comparativamente para distintas campañas, los modos de construcción de la imagen de Lula, así como las variaciones en la presencia, por ejemplo, de la sigla, logo y referencias partidarias (Carvalho, 2011; Panke, 2011; Dias, 2013). Así, por ejemplo, Carvalho (2011) recorre la estigmatización de la militancia petista en la campaña de 1989, y señala, para la elección de 1994, las restricciones en la regulación legal de las campañas televisivas que impidieron al PT transmitir las grabaciones de las Caravanas da Cidadania que habían sido filmadas como parte de los recorridos territoriales de Lula. La medición de la imagen partidaria en los programas electorales del HGPE realizada por Dias (2013) indica una mayor presencia de la misma en la campaña petista respecto de otras, pero, a la vez, un descenso después de 1989, con un piso en 1998, y un nuevo ascenso en 2002, para volver a bajar en 2006 y subir levemente en 2010. La campaña de 2006, en el contexto de los coletazos del escándalo del Mensalão, que alcanzó penalmente a una parte de la cúpula del PT, aparece, para ese artículo y también para otros trabajos (Carvalho, 2011; Panke, 2011), como una instancia en la que el sello, la 
iconografía y hasta los colores del PT parecían ser ocultados y disociados de la imagen del candidato presidencial.

Albuquerque (1999), por su parte, destaca la inclusión en la propaganda electoral de escenas de la campaña en la calle, con activistas que daban testimonio y aclamaban al candidato, así como con la presentación de la evolución de las encuestas de opinión pública y apelaciones emocionales al involucramiento del elector, denominando ese tipo de mensajes como "metacampaña". Otros trabajos se han referido al uso, ya para 2002, de una batería novedosa de recursos profesionalizados de marketing político y una intensa reformulación de la imagen del candidato (Rubim, 2003; Rocca Rivarola, 2011) ${ }^{15}$. Ribeiro (2008) incluso se refiere a la campaña de Lula de 2002 como la más estructurada, hasta entonces, de la historia petista:

Una gran y profesionalizada estructura, con una extensa red de apoyo en los Estados (periodistas, asesores de prensa etc.), programas de televisión sofisticados, centenas de encuestas cualitativas y cuantitativas. Los profesionales tomaron el lugar de la militancia, de la misma forma que el HGPE delegó en los actos de campaña una función accesoria, generar imágenes entusiastas para la televisión. Para atraer más público, fueron transformados en Showmícios, con la contratación (por parte del Directorio Nacional del PT) de artistas con fuerte apelación popular, acompañados por una amplia y sofisticada estructura técnica. Fue el ápice del proceso de modernización de las campañas del PT (Ribeiro, 2008, p. 119).

Las cuatro campañas electorales que aborda nuestro propio artículo (2007 y 2011 en Argentina; 2010 y 2014 en Brasil) también han sido foco de estudios previos, sólo que no desde el objetivo de identificar e interpretar de modo comparativo el lugar visualmente asignado en ellas a la militancia oficialista.

En Argentina, Grosman (2012) examina el discurso de campaña en 2007 y 2011 a partir de ejes temáticos, como el "antes y después del modelo kirchnerista", mientras que Vitale y Maizels (2011) atribuyen al discurso de CFK en 2007 dos imágenes, la pedagógicaexperta y la de la femineidad. Iazzetta (2012) identifica a la campaña de 2007 como la de menor calor popular en muchos años (traduciéndose luego en niveles récord de ausentismo electoral). Por su parte, la campaña de 2011, como ya vimos, motivó algunos estudios acerca del discurso y estrategias de CFK y otros candidatos en las redes sociales.

Para Brasil, numerosos trabajos han surgido alrededor de la campaña televisiva de 2010 (HGPE y spots publicitarios o "inserciones"). Además de los aportes en torno al modo

\footnotetext{
15 Se ha argumentado (Rubim, 2003; Rocca Rivarola, 2011) que la campaña de 2002 parecía orientada a desanudar progresivamente la asociación histórica y vigente en la opinión pública entre la figura de Lula y la trayectoria de lucha social y radicalidad política del PT. En ese sentido, era ilustrativa la frase "El sindicalista espanta", pronunciada por Duda Mendonça, publicista encargado de la campaña, en el documental Entreatos (Moreira Salles, 2004) en una conversación con Lula sobre qué decir y cómo actuar en uno de los debates presidenciales.
} 
en que fueron organizados los segmentos por parte de los candidatos (Oliveira y Martins, 2013), entre los principales argumentos sobre el perfil y mensajes de esa campaña, aparece el del rol y presencia de Lula en esos programas como patrocinador, patrono o padrino de Dilma, a través de intentos de asociación de ambas figuras $y$, con ello, lograr una transferencia de popularidad (Carvalho, 2011; Panke, 2011; Aquino y Luques, 2012; Bachini, 2013; Dias, 2013; Telles y Pires, 2013; Martins, 2014). Dentro de esas líneas de investigación, se perfila una discusión acerca del tipo de asociación formulada, ya sea una de tipo personal y emocional (Bachini, 2013) o bien en tanto vinculación de tipo partidario o afirmación de un proyecto político compartido (Dias, 2013). Otros argumentos complementarios han postulado la presentación de Dilma en la campaña televisiva como experta, mano derecha o portadora de capacidad técnica (Panke, 2011; Panke et al., 2011; Silva y Leal, 2011), o incluso como figura maternal o "madre del pueblo" (Panke, 2011; Pires, 2011; Freitas, 2013). Y finalmente, algunos trabajos han examinado la presencia del partido en el HGPE, resaltando una mayor visualidad del sello y los colores respecto de 2006 (Dias, 2013) o, por el contrario, señalando "la desaparición de la palabra PT" en las menciones explícitas dentro de la campaña de TV de 2010 (Telles y Pires, 2013). E incluso se ha señalado un fenómeno de personalización de la política evidenciado en las campañas de Serra y Rousseff en 2010 (Leal y Vieira, 2009; Tavares, 2013). Desde otra perspectiva, Borba (2012) analiza las estrategias de inclusión y ubicación de campaña negativa en los spots publicitarios de 2010, en el marco de una legislación considerablemente restrictiva.

Aunque la literatura es un poco más escasa todavía en relación con la campaña de 2014, algunos trabajos han examinado el HGPE de Dilma desde la perspectiva de análisis del discurso (Bartolomeu y Ludovice, 2015; Parzianello, 2016) ${ }^{16}$. Desde otro enfoque, Massuchin y Tavares (2016) continúan con los aportes mencionados anteriormente en el abordaje de los contenidos publicados en los sitios web de los candidatos y su retroalimentación con los otros medios de campaña como la TV ${ }^{17}$. Esa "interactividad" entre distintos medios de campaña también es observada por Oliveira, Martins y Leal (2015) al advertir la introducción de recursos de Internet en el formato televisivo (links a redes sociales, promoción de la producción de fotos selfies etc.), y también por Lima y Panke (2016), que relevan la participación y reacción online de los electores frente a la exposición de los candidatos en sus plataformas web. Trevisol y Perin (2014), por su parte, subrayan el esfuerzo del HGPE por incrementar la popularidad de Dilma luego de las protestas de junio de 2013 y por asociar la ideología petista a un enfoque en las clases inferiores, la transformación y la extinción de la corrupción. Asimismo, identifican el uso dado al perfil de Dilma como antigua militante juvenil, elemento que será retomado, indagado e interpretado en nuestro artículo. Otro estudio que ha resultado valioso para nuestro propio

\footnotetext{
16 Hay también aportes desde esa misma perspectiva en torno a la campaña de Dilma de 2010 (Marques, 2012).

17 También han emergido análisis de los HGPE de Dilma en conjunto con su comunicación gubernamental por fuera del período de campaña electoral o "campaña permanente" (Fernandes et al., 2016).
} 
análisis es el de Castro (2016), donde se exploran los contenidos del HGPE de cinco candidatos a presidente en 2014, incluida Rousseff, y se concluye que las manifestaciones de 2013 tuvieron poca atención en relación con otros temas de campaña, pero que, a la vez, el HGPE fue utilizado por los candidatos para vehiculizar sus respectivas posiciones sobre aquellas protestas, enfatizando aspectos diferentes sobre el mismo fenómeno heterogeneidad de ponderaciones que también ha sido indagada por Moreira y Martins (2016).

Y finalmente, aludiendo a varios de los aspectos ya mencionados para el HGPE de 2010 y 2014, Luchesi (2016) estudia comparativamente ambas campañas resaltando secuencias comunes (como el énfasis en programas sociales o la presencia de Lula) y rupturas (mensaje de continuidad en 2010 versus noción de cambios e "ideas nuevas" en 2014, mayor ataque a adversarios en 2014 etc.).

\section{El lugar visual del colectivo militante en las campañas de Cristina F. Kirchner y Dilma Rousseff}

Argentina

Legislación y reglas

El Sistema Electoral de la Argentina para las elecciones de presidente y vicepresidente es mayoritario, con elecciones directas y con un sistema de doble vuelta, en caso de que ninguna de las fórmulas presidenciales obtenga más del $45 \%$ de los votos, o más del $40 \%$ pero con una diferencia del $10 \%$ con respecto a los demás candidatos. Estos cargos se eligen cada cuatro años, con posibilidad de una reelección. En la Argentina, a diferencia de Brasil, el voto es emitido en papel y sin digitalización del sistema para ninguna instancia nacional ( $y$ con listas cerradas para las elecciones legislativas) ${ }^{18}$. Para las elecciones celebradas en el año 2007, cuyos spots para el FPV este artículo analiza, regía la "Ley Orgánica de Los Partidos Políticos" (23.298) sancionada y promulgada en 1985. Según esta norma la nominación de candidatos le correspondía a los partidos políticos para los cargos electivos. Para las elecciones presidenciales de 2007, no existía reglamentación que prohibiera el financiamiento de los partidos por parte de entes privados, aunque sí se establecía, según la Ley 26.215, promulgada ese mismo año, un límite a los recursos privados.

Cabe mencionar que la Ley 26.215 (artículo 43) establecía la asignación de espacios en los medios de comunicación como competencia del Estado: "El Estado otorgará

\footnotetext{
18 En 2016, el gobierno de Mauricio Macri impulsó una reforma electoral que incluía entre sus puntos la boleta electrónica (aplicada hasta entonces sólo en las elecciones locales de la ciudad de Buenos Aires y la provincia de Salta). El proyecto fue aprobado, en la Cámara de Diputados, con algunas modificaciones respecto del original. Pero luego, en el Senado, el proyecto naufragó, siendo postergado sin fecha determinada de tratamiento.
} 
a los partidos o alianzas que oficialicen candidaturas, espacios en los medios de radiodifusión, para la transmisión de sus mensajes de campaña". Las 500 horas de radiodifusión televisiva asignadas eran divididas de forma equitativa en un $50 \%$ entre las coaliciones o alianzas que oficializaban candidaturas, mientras que el $50 \%$ restante de horas se distribuía de forma proporcional a la cantidad de votos obtenidos por cada alianza o coalición en las elecciones de diputados nacionales previas a los comicios presidenciales, y cuyo piso mínimo hubiera sido del $1 \%$ del padrón electoral. Sin embargo, ésta y otras reglamentaciones previas no definían límites a la cantidad de tiempo que podía comprarse de modo privado y complementario en la televisión con fines de campaña electoral. Como resultado, los avisos o spots pagos fuera de ese tiempo regulado devinieron uno de los más significativos gastos de campaña para los partidos desde la redemocratización (D'Alessandro, 2017).

La campaña de 2011 se celebró, en cambio, bajo otro marco legal. En diciembre de 2009, se sancionó la ley de Partidos Políticos (26.571), llamada "Ley de democratización de la representación política, la transparencia y la equidad electoral". La modificación legal de 2009 implicó un cambio en la forma de presentación a elecciones por parte de los partidos.

Por un lado, estableciendo un piso mínimo de votos $(1,5 \%)$ en las elecciones "Primarias, Abiertas, Simultáneas y Obligatorias" (PASO) para poder competir luego en las elecciones generales. Es decir, se inauguraba y oficializaba una instancia previa a las elecciones generales, que hasta entonces había quedado supeditada a la voluntad de los partidos de realizar esos comicios y de modo interno. Al menos en teoría según el texto de la ley, se le asignaba a las PASO la función de definir por votación, para cada partido o frente electoral, cuáles serían los candidatos habilitados para presentarse luego, es decir, concibiendo una competencia interna dentro de cada frente en la instancia de las PASO, pero de modo abierto y obligatorio (todos los ciudadanos participaban de un mismo comicio en el que se ofertaban las distintas precandidaturas de cada frente, todas juntas).

Para la campaña electoral, que es el punto directamente relacionado con nuestro propio análisis, la ley habilitaba el inicio de la publicidad electoral audiovisual recién veinte días antes de la fecha de las elecciones primarias, mientras que, luego, para las elecciones generales, la campaña electoral comenzaba 35 días antes de los comicios, debiendo finalizar 48 horas antes.

Los espacios de publicidad electoral en la televisión y las emisoras de radiodifusión eran asignados por sorteo público y la distribución estaría a cargo, exclusivamente, de la Dirección Nacional Electoral del Ministerio del Interior (en porcentajes similares a la ley anteriormente vigente, $50 \%$ equitativo y $50 \%$ proporcional al voto obtenido en elecciones previas), no pudiendo comprarse más tiempo de exhibición de spots más allá de las 600 horas reguladas por la ley y distribuidas desde el Estado. En cuanto al tiempo otorgado a cada partido, la ley obligaba a todas las emisoras a ceder el diez por ciento $(10 \%)$ del tiempo total de su programación para la transmisión de los spots de publicidad electoral. 
Y la franja horaria para la distribución de los horarios (entre las 7 AM y la 1 AM), y la ubicación de los spots en los distintos medios se definían también por sorteo público, con el fin de un reparto equitativo. La ley garantizaba para todas las agrupaciones que oficializaran listas de candidatos la rotación en todos los horarios y la transmisión de sus spots al menos dos veces por semana en horario central en las distintas emisoras. De este modo, se producía cierta igualdad entre los partidos o frentes en las condiciones de acceso al espacio de tiempo de aire en televisión y radio, aunque la disparidad seguía advirtiéndose en la calidad de las piezas, cuya producción estaba a cargo de cada fuerza política (D'Alessandro, 2017).

En cuanto al financiamiento, el 50\% del aporte estatal a los partidos políticos para sus campañas electorales se distribuía de modo igualitario. Y se prohibían las donaciones de personas jurídicas y contribuciones anónimas, mientras que los aportes privados tendrían límites en los montos. Al igual que en Brasil, el contenido de la ley no frenaba, en la práctica, la existencia de donaciones no declaradas o incluso la llegada de donaciones de empresas disfrazadas como de individuos (integrantes de los directorios o de su planta de empleados).

Análisis de los spots de campaña de Cristina Fernández de Kirchner en 2007 y 2011

El análisis de los spots televisivos para las elecciones presidenciales de los años 2007 y 2011 permite reflexionar sobre el modo en que los contextos históricos fueron incidiendo sobre los contenidos y mensajes emitidos durante las campañas que correspondieron a cada año, y específicamente sobre el lugar visual asignado al colectivo militante oficialista en cada una de esas coyunturas, entre las cuales se produjo la implementación de la Ley de las PASO, la muerte de Néstor Kirchner y la aparición pública y crecimiento de la agrupación La Cámpora, y otras organizaciones militantes menores con una marcada composición juvenil.

En comparación, se puede notar un cambio entre los spots emitidos en 2007 y los de 2011 , en términos del estilo, la estética y el contenido. Frente a la escasa presencia del colectivo militante en 2007, éste se vuelve una constante en los spots del Frente para la Victoria (FPV) en 2011. No se advierten, en cambio, diferencias, en 2011, en la importancia del rol de este colectivo en los spots emitidos ante las elecciones primarias y, posteriormente, de cara a las elecciones generales.

\section{7}

En el 2007, el Frente para la Victoria (FPV) se presenta a elecciones con una fórmula concertacionista, que combinaba a los dos partidos históricos, el peronismo y el 
radicalismo (o, al menos, a una parte de los mismos) ${ }^{19}$ : Cristina Fernández de Kirchner como presidente y Julio Cobos como vicepresidente.

En los once spots analizados se puede observar que el FPV casi no incorpora visualmente al colectivo militante. Lo que sí aparece es la alusión a un pasado reciente que tiene un antes y un después de 2003 (inicio del mandato de Néstor Kirchner).

A modo de ejemplo, en el spot "¿Qué es el FMI?" se resalta la crisis de 2001 y cómo ésta ha quedado en el olvido. En otro spot ("Abuelo"), un hombre mayor habla de la importancia de votar, comparando el presente con épocas en las cuales no se podía sufragar, debido a la interrupción del orden democrático. La pieza "Recuperar la dignidad del trabajo" hace referencia, por su parte, a la inclusión laboral y las oportunidades de trabajo generadas por el gobierno de Kirchner. En ninguna de estas publicidades aparece representado visual o simbólicamente, ni siquiera de forma incipiente, el colectivo militante oficialista, sino que, más bien, se apela a mostrar ciudadanos comunes y cómo sus respectivas vidas cambiaron a lo largo del gobierno kirchnerista. En esta línea, se puede observar que tampoco hay menciones partidarias, ya que el slogan final es "Cristina, Cobos y vos", sin presencia ni proyección de algún símbolo o sello, ni del FPV, ni del PJ, ni de la UCR. Y ese slogan se complementa con otro, a lo largo de las piezas, que sugiere una línea de continuidad, pero también una imagen de un proyecto inconcluso, aunque sin especificar qué se planifica para completarlo: "Sabemos lo que falta, sabemos cómo hacerlo".

En el spot "La Concertación", un tanto diferente en términos estéticos a los demás, se hace alusión a la confluencia a partir de que "cada uno ponga lo mejor que tiene", llamando a la unión de "todos" con imágenes de figuras emblemáticas tanto del radicalismo (Balbín, Frondizi, Illia etc.) como del peronismo (Evita, Perón) -algo que se repite en el spot "Imágenes históricas, peronistas/radicales. Cristina, Cobos y vos"- o bien llamando a la concertación entre diferentes sectores (trabajadores, empresarios, campo, industria). En esta pieza, sí se muestran algunas imágenes, a la par de las de los dirigentes históricos mencionados, de multitudes en actos electorales o de gobierno. La intensidad y sistematicidad que cobrarán las mismas para 2011, sin embargo, es notablemente contrastante.

\section{1}

A partir de la observación de 27 spots emitidos antes y después de las PASO, es posible identificar un patrón generalizado en los mismos: se traza una línea de continuidad entre el gobierno de Néstor Kirchner y el primer mandato de CFK, pero afirmando al

\footnotetext{
19 Es importante aclarar que otras fórmulas presidenciales en 2007 también incluían en sus candidaturas -o en su electorado- al peronismo y al radicalismo. Es el caso de E. Carrió, que venía recibiendo votos provenientes del radicalismo, y que había sumado algunas líneas peronistas dentro de su partido, la Coalición Cívica. También, de R. Lavagna, en cuyo frente electoral, Una Nación Avanzada (UNA), coexistían dirigentes y redes peronistas y radicales. Y de A. Rodríguez Saa, que representaba a peronistas opositores al gobierno.
} 
segundo como una fase superadora. Algunos de los spots están relacionados con los planes y las políticas públicas de inclusión social impulsados por el gobierno, como el Plan de Primera Vivienda y el Plan Trabajar, y se observa un énfasis en los logros en la educación y la política científica ${ }^{20}$.

Todos los spots, asimismo, hacen alusiones a las conquistas, victorias y valores sobre las que la candidata procura apoyarse. Ahora bien, a diferencia de 2007, en 2011 esas victorias o logros se perfilan recurrentemente como personificados en figuras de militantes. Las categorías que la voz en off va nombrando -madres, jóvenes etc.- son representadas visualmente por militantes marchando en movilizaciones, caminando hacia un acto político, cantando, agitando sus brazos, llorando emocionados, saludando a CFK, apoyándola activamente. Cada spot parece apelar, así, a una identidad, a través de un colectivo determinado y movilizado. Ello puede percibirse, por ejemplo, en el spot "La fuerza de los jóvenes", en la que éstos no son individuos aislados, sino jóvenes movilizados en distintas proyecciones de actos políticos, que agitan banderas, cantan, y que portan una identidad política y militante.

Hay que destacar que, en el análisis del colectivo militante, no se advierte un contraste marcado entre los spots emitidos antes de las PASO y después de las PASO, de cara a las elecciones generales. Lo que sí cambia de unos a otros es la leyenda presente en los carteles que pueblan las imágenes: de "Fuerza Cristina" pasan a decir "Fuerza Argentina". Varios spots de 2011, por otro lado, apelan a lo emocional, con valores como el amor (spot "La Fuerza del Amor"), o mismo refiriéndose a Néstor Kirchner como una suerte de guardián de la nación, como sucede en el spot "La Fuerza de Él".

Mientras que, en 2007, los spots formulaban una comparación con el pasado (recordando la crisis del 2001, la gravitación del FMI sobre la política económica, el desempleo, la imposibilidad de votar durante los gobiernos de facto), en el 2011 no hay tanto una comparación entre períodos sino un discurso emocional de ponderación de lo realizado durante los ocho años de gobiernos kirchneristas. Y, a través de distintos recursos visuales, se sugiere una suerte de inmortalidad simbólica de Kirchner, y el engrandecimiento de CFK. La sucesión de historias particulares que van integrándose en una épica común y la virtual ausencia de menciones a su nuevo compañero de fórmula, Amado Boudou (salvo en los zócalos del final) acaban por volcar el peso visual en la figura de CFK. Pero, esta vez, a diferencia de 2007, el énfasis también está puesto en el vínculo

\footnotetext{
20 Uno de esos spots, "La fuerza de Cecilia", suscitó polémica después de su emisión. La voz en off de la investigadora decía que había tenido que dejar el país en 2002 (en plena crisis económica), cuando consiguió una beca en Alemania. Y se refería a la "fuga de cerebros" que había sufrido el país. Luego, en el 2009, seguía Cecilia, la embajada argentina había convocado a los científicos argentinos que vivían en el exterior, ante lo cual vino "a trabajar a la universidad pública para devolverle a mi gente todo lo que hizo por mí". Sin embargo, días después de su emisión, algunos medios reprodujeron datos oficiales del Consejo Nacional de Investigaciones Científicas y Técnicas (CONICET), que mostraban que la investigadora había tenido una beca exclusiva financiada por ese organismo argentino entre 2002 y 2007, realizando estancias de investigación en Alemania durante todo el período. Y que recién se había instalado formalmente en Alemania en 2007, durante los propios gobiernos kirchneristas.
} 
de la candidata con el colectivo militante movilizado. Éste último está representado, entonces, de modo constante en los spots, a través de sus acciones típicas: movilizaciones, actos, saludos a la candidata, agite. Incluso en la frase que atraviesa la campaña "La fuerza de un país, de un pueblo, la fuerza de 40 millones de argentinos": la imagen que acompaña ese mensaje no es la de personas comunes en distintos lugares del país, como en otras propagandas o spots, sino la de una multitud militante, que escenifica un acto político.

La representación visual de la militancia en los spots de 2011 llega incluso a mostrar explícitamente a organizaciones específicas dentro de ese colectivo de sustentación activa, como La Cámpora, exhibiendo sus banderas y camisetas. En 2011, uno de los spots podría ser interpretado como un resumen de toda la campaña televisiva de CFK de ese año. El spot "Fuerza Argentina. Cristina Fernández de Kirchner Presidenta 2011" es tal vez el más paradigmático del contraste con la campaña de 2007. La pieza ya comienza con aplausos y ovaciones de un acto implícito, dado que no se muestran imágenes, sino sólo el sonido. Luego, aparece, entre la multitud en la calle, Victoria Montenegro, nieta recuperada por las Abuelas de Plaza de Mayo ${ }^{21}$. Su figura, en colores, y quieta entre personas en blanco y negro, que caminan, comienza a sonreír y mirar a la cámara. Y no es la figura de cualquier nieto recuperado, sino la de alguien involucrada en un respaldo activo al gobierno, dado que Montenegro es militante de la corriente Kolina 22 . La voz en off de CFK señala: "me gusta ver que los jóvenes se hagan respetar", mientras la imagen que ilustra estas palabras es la de grupos de jóvenes militantes en la calle, agitando y cantando. Más adelante, las "amas de casa" que la misma voz menciona tampoco son amas de casa comunes en sus hogares, sino que se las ve movilizadas, en un acto o manifestación, aclamando, agitando. Cuando CFK sostiene que mira "a un argentino o argentina a los ojos", el spot muestra a una mujer emocionada, abrigada con una bandera, en un acto político. Y luego, se muestra a un joven vestido con una remera de la Cámpora. En otros términos, los "argentinos", los "jóvenes" y demás categorías sociales a los que está refiriéndose la candidata aparecen ilustrados, representados o ilustrados por militantes oficialistas. Los últimos segundos del spot, en los que cada categoría acaba confluyendo en la frase "la fuerza de un país", potencian elocuentemente el simbolismo: se trata del país movilizado, de la militancia activa.

Un elemento que da cuenta de la importancia dada en los spots de 2011 al colectivo militante kirchnerista es el momento final de cada uno de los spots. Tanto en las piezas de cara a las PASO como para las elecciones generales, los segundos finales reflejan imágenes de multitudes agitando banderas y, reflejando con ellas, una identidad clara y consolidada.

\footnotetext{
21 Abuelas de Plaza de Mayo es una organización creada en 1977 con el fin de localizar y restituir a sus auténticas familias a los nietos desaparecidos (secuestrados o bien nacidos en cautiverio) en la última dictadura militar.

22 Kolina fue fundada en 2010 y es liderada por Alicia Kirchner, hermana del ex presidente, ministra de Desarrollo Social durante los gobiernos kirchneristas y, desde 2015, gobernadora de la provincia de Santa Cruz. Ha tenido un importante acceso al Estado, especialmente en el Ministerio de Desarrollo Social y en asambleas legislativas.
} 
Si bien cada spot cuenta algo diferente, todos cierran con una operación similar de sentido: exhibir la parte representando al todo. Las frases "La Fuerza de un Pueblo" y "La Fuerza de un País" son ilustradas por (y reducidas a) una multitud de militantes movilizada frente a CFK (quien está de espaldas) agitando banderas argentinas.

Brasil

Legislación y reglas

Al igual que en Argentina, el sistema electoral brasileño para las elecciones de presidente y vicepresidente era, en 2010 y 2014, mayoritario, con elecciones directas y un sistema de segunda vuelta.

Los cargos también duran cuatro años, con posibilidad de una reelección. La diferencia radica en el sistema de votación, que es digitalizado en Brasil, y en el carácter de las listas para las elecciones legislativas: lista abierta o nominal, mediante la cual el votante puede escoger un candidato específico, a través del marcado de un código en la máquina de votación luego del número correspondiente a la coalición, o bien, puede limitarse a formular un voto na legenda, sin definir luego un candidato específico, sino eligiendo a toda la coalición o partido. Tal como afirma Nicolau, las campañas están pobladas comúnmente de conflictos intracoaliciones, una hiperpersonalización y, también, una hiperfragmentación partidaria (Nicolau, 2015), algo que no sólo afecta a las elecciones legislativas sino también a la elección presidencial simultánea.

Otros dos problemas derivados del diseño institucional electoral brasileño que han motivado diferentes propuestas de reforma (Fleischer, 2005) son las muy frecuentes fugas partidarias y de bloque (desafiliación y afiliación a nuevos partidos por parte de la dirigencia política, así como cambios radicales y repentinos entre los bloques partidarios en el Congreso), y la cuestión del financiamiento privado paralelo (oculto en las rendiciones de cuentas) o "Caixa 2", que no ha cesado de crecer en el marco del sistema de financiamiento mixto (público y privado) de campañas.

La propaganda electoral en televisión, por su parte, está regulada por dos leyes, la 9096/1995, o Ley de los Partidos Políticos, y la 9504/1997, o Ley de las Elecciones. La Ley de los Partidos establece el Fondo Partidario, cuya principal fuente de recursos sale del presupuesto nacional, y que es repartido mensualmente a los partidos ( $5 \%$ en partes iguales y $95 \%$ según los votos obtenidos en la última elección de diputados nacionales). Luego, son los partidos los que definen cuánto de esos fondos usarán para la campaña o para fines internos y los que, a través de sus directorios nacionales, distribuyen parte de esos recursos a sus órganos estaduales y municipales. Mancuso (2015) sostiene que la relevancia del fondo partidario para las campañas electorales es pequeña, representando aproximadamente un $5 \%$ de lo que los partidos reciben de empresas, por ejemplo. 
La Ley de las Elecciones prohíbe la propaganda paga en la radio y la televisión, y determina la reserva de espacio en ambas para la propaganda gratuita (a cambio de compensaciones fiscales para esas emisoras). Así, como en Argentina a partir de la ley de las PASO, el Horário Gratuito de Propaganda Eleitoral o HGPE en Brasil garantiza un espacio a todos los partidos para informar sus propuestas. Pero como elemento particular del caso brasileño, Borba (2012) identifica dos fuentes distintas del horario gratuito: la propaganda electoral transmitida en bloques ("programa electoral", que en el caso del PT en 2010 y 2014 fue aproximadamente de 10 u 11 minutos de duración) y las "inserciones" comerciales o spots (piezas de 30 segundos, que podían ser divididas en dos unidades de 15 segundos o sumarse entre sí en una de un minuto) ${ }^{23}$. Tanto el espacio para la propaganda electoral en bloques como para las inserciones se distribuye entre los partidos o coaliciones: $1 / 3$ es dividido en partes iguales entre todos y los 2/3 restantes, de acuerdo al tamaño de las bancadas parlamentarias (Borba, 2012). El Tribunal Superior Electoral (TSE) establece limitaciones de ubicación y de contenido a la propaganda electoral, especialmente para el caso de los spots: sortea el día y bloque horario de emisión (hay cuatro por día) -el horario exacto de transmisión dentro de cada bloque es, en cambio, definido autónomamente por las emisoras- y restringe, como ya ha sido mencionado en la introducción de este artículo, su contenido. En adelante, utilizaremos la sigla HGPE para referirnos sólo a los programas en bloque.

Aunque la capacidad de influencia sobre la decisión del voto por parte de la propaganda electoral televisiva regulada es materia de discusión ${ }^{24}$, dos datos dan cuenta de su importancia como fuente de información en la campaña. Por un lado, el altísimo nivel (90\%) de acceso de los hogares a la TV, similar a EEUU (Borba, 2008). Y, por otro, los elevados índices de audiencia del HGPE: en 2010, 53\% afirmó haberlo visto para el primer turno; y 60\%, para el segundo (Dias, 2013).

\section{Análisis HGPE de Dilma Rousseff en 2010 y 2014}

A diferencia del caso argentino, en Brasil, ambas campañas de televisión, 2010 y 2014, asignan un espacio del HGPE a la proyección de imágenes de los apoyos de la militancia y la movilización orgánica en actos políticos (comícios). Sin embargo, es la campaña por la reelección de Dilma, en 2014, la que resalta más ese elemento y le dedica más tiempo. E incluso incorpora un segundo modo de representación de la militancia, a

\footnotetext{
23 Albuquerque (2005) considera que estos dos formatos diferenciados, los programas en bloque y las inserciones, dan lugar a dos tipos distintos de estrategia de campaña: uno más periodístico, que se renueva diariamente en los programas, y otro más publicitario, que repite puntualmente un mensaje en los spots. 24 Para Telles y Pires (2013), el HGPE es capaz de influir sobre la intención de voto, activando o consolidando disposiciones previas, y opera como principal fuente de información para el elector común. El HGPE consolidaría el voto de los fieles y captaría la atención de indecisos. Veiga (2002), por su parte, sostiene que el HGPE es visto por el electorado como importante fuente de información, pero que sólo le da argumentos al votante para sus conversaciones cotidianas, que es donde se cristalizan las opiniones.
} 
través de la alusión a la trayectoria de Rousseff como militante juvenil en la lucha contra la dictadura (1964-1985).

\section{0}

En términos de duración, los segmentos dedicados al colectivo militante son más cortos que lo que se advertirá en 2014, no superando, en general, el $10 \%$ de la duración total de cada programa (variando entre siete segundos y un minuto). Con respecto a la frecuencia y ubicación dentro del HGPE, entre la campaña para el primer y segundo turno electoral, se advierte un aumento y mayor diseminación de las imágenes del colectivo militante a lo largo de cada programa ${ }^{25}$. Estos segmentos se caracterizan por una música acelerada e intensa, similar a una samba, y por una voz en off que presenta, paralelamente, resultados de encuestas de opinión pública, mostrando el ascenso de la intención de voto de Dilma ${ }^{26}$, mientras que la imagen de fondo está constituida por actos militantes de campaña (con referencias a la ciudad en la que se realizaron) ${ }^{27}$. El sonido agregado (editado) que acompaña el segmento incluye ovaciones.

Tanto en 2010 como en 2014, en este modo de representación visual del colectivo militante predominan imágenes de banderas flameando (blancas y rojas, con la inscripción "Dilma 13", o similares, y en algunos casos, propias de las organizaciones presentes) y vestimenta roja, denotando una presencia aplastante de militancia organizada. La candidata es enfocada de frente o de espaldas mirando al público, y saludando de modo general o acercándose individualmente a militantes parados detrás de vallas. Y se reproducen pequeños fragmentos de discursos, tanto de Dilma como de Lula, en estos actos. En algunos casos, además, sobre todo en el último tramo de la campaña, se apela al recurso de presentar algunos testimonios de esos militantes en los alrededores del acto $^{28}$. No obstante, lo que predomina de modo abrumador en el HGPE de 2010 no son estos testimonios, sino los de personas "comunes", con nombre y apellido, entrevistadas en sus casas o lugar de trabajo, sobre todo beneficiarios de programas sociales o políticas públicas del gobierno de Lula, que van contando cómo sus vidas fueron transformadas.

\footnotetext{
25 En menos de un cuarto de los programas del primer turno, los segmentos representativos de la militancia aparecían intercalados en varios momentos del programa. En el segundo turno, ello ya ocurría en la mitad de los programas, exhibiendo entonces una mayor presencia y más recurrente de la imagen del colectivo militante.

26 Analizando la campaña de 2010 en Brasil, Cervi, Massuchin y Tavares (2012) denominan este tipo de operación como "metacampaña", es decir, mensajes que se constituyen a partir de informaciones sobre la campaña en sí.

27 Telles y Pires (2013) sostienen que, en algunos casos, como la convención del PT del 13/06/2010 (oficialización de la candidatura de Dilma), es posible que los eventos hayan sido escenificados y preparados ya para la TV.

28 A modo de ejemplo, en el programa del 15/10/2010, se escuchan voces de testimonios militantes: "Dilma va a ser la gran guerrera", "nadie aquí es bobo, queremos a Dilma, vamos con Dilma", o "Estoy con Dilma y no desisto".
} 


\section{4}

Este mismo modo, recién descripto, de aludir a la militancia -a través de filmaciones de actos de campaña (cerrados, en predios abiertos o incluso en la calle), con tomas de multitudes, banderas, cantos y del público militante mismo- está presente en 2014 y con mayor relevancia.

Ese año, no sólo los segmentos dedicados al colectivo militante duran más (en la segunda mitad de la campaña, por ejemplo, representan más de un cuarto del contenido de cada programa, y hacia el final del segundo turno, más de la mitad del mismo), sino que, además, adquieren otro carácter. En vez de funcionar como imagen de fondo para la presentación de encuestas de opinión sobre el ascenso de la candidata en intención de voto (es decir, el énfasis en el potencial apoyo del electorado anónimo), como sucedía en 2010, ahora son el marco del anuncio, por parte de la voz en off, de apoyos más orgánicos o colectivos que va acumulando la candidata. Gobernadores, senadores, diputados electos (después del primer turno), centrales sindicales y sindicatos, organizaciones de juventud, organizaciones que impulsan la reforma política, artistas organizados y dirigentes de otros partidos fuera de la coalición electoral van siendo mencionados como adherentes a la candidatura de Dilma ${ }^{29}$. El HGPE de 2014 pone, entonces, un énfasis mayor en ir mostrando la acumulación, a lo largo de la campaña, de apoyos "orgánicos", y hasta un colectivo adherente al que la voz en off del locutor alude reiteradamente como "el Brasil que se moviliza" o "que lucha por más empleos, más salarios, por la reforma política...", mientras se exhiben actos militantes en la calle o en predios cerrados.

Pero, además, el HGPE de 2014 introduce un modo particular y novedoso, respecto de 2010 y también respecto del caso argentino, de representación visual de la militancia, a través de la alusión a y ponderación de la trayectoria militante de Rousseff en su propia juventud durante la dictadura militar.

Aunque la actuación de Dilma Rousseff como militante juvenil en organizaciones armadas -primero, en la organización Política Operária (Polop), y luego en el Comando de Libertação Nacional (Colina), redenominado Vanguarda Armada Revolucionária Palmares (VAR-Palmares)- fue motivo de una vasta cobertura en la prensa gráfica y en los canales de TV en 2010, a menudo en formato de denuncia y crítica, el HGPE de Dilma en esa ocasión se hace escaso o nulo eco de aquella controversia, y elude referencias a la misma. En relación con este punto, es notable lo sucedido con la presentación de la biografía de Rousseff en los programas del HGPE de 2010. Un segmento incluido en la gran mayoría (dos tercios) de los programas electorales del primer turno se compone de una suerte de biografía de la candidata, con una sucesión cronológica de fotos en blanco y negro

\footnotetext{
${ }^{29}$ A diferencia de la campaña de 2010, que mostraba frecuentemente resultados de encuestas, el HGPE de 2014 presentó cifras de intención de voto recién hacia el final del primer turno (programa 35०, 27/09/14, a ocho días de la elección) y también del segundo (programa $64^{\circ}$, del $21 / 10$, a menos de una semana de la contienda).
} 
acompañadas del relato de un locutor como voz en off y textos, presentando hitos de su vida. Ahora bien, a excepción de los dos programas iniciales del HGPE $\left(1^{\circ}\right.$ y $2^{\circ 30}$, del $17 / 08 / 10)$, que incluyen referencias en esa biografía a su etapa como militante política durante la dictadura y su detención ${ }^{31}$, en el resto de los programas (22), esta biografía quedará acotada a su carrera en la función pública, suprimiéndose toda referencia a su militancia armada, a la dictadura o a su detención ${ }^{32}$. Es decir, aunque durante el período de campaña, la participación juvenil de Dilma en organizaciones armadas será un tema recurrente en la cobertura de los medios (Ângelo, 2012; Fernandes, 2012; Gouvêa, 2014), el HGPE tiende a omitir ese aspecto de la trayectoria de la candidata ${ }^{33}$.

En 2014, en cambio, el HGPE de Dilma toma esa trayectoria militante (e incluso su detención), la despoja de la negatividad que la prensa le dio en 2010 y la reviste de un carácter épico, convirtiendo a Dilma en heroína y protagonista de la resistencia contra la dictadura militar, con un slogan que sintetiza esa operación simbólica: "Dilma corazón valiente" 34 .

La ponderación del pasado militante de Dilma durante la dictadura se efectúa en 2014 a través de la utilización de distintos recursos. En primer lugar, con dos fotos representativas de ese período (ver Anexos). Desde el primer programa electoral, y de modo reiterado en gran parte de los siguientes, el jingle "Dilma Corazón Valiente", que se vale de imágenes de gente común escuchándolo en su casa, camino al trabajo etc., así como de selfies que la candidata se toma con adherentes, y de momentos de actos de campaña, exhibe, al llegar a su fin, dos fotos que retratan crudamente aquella etapa juvenil de Rousseff como militante y como presa política.

\footnotetext{
30 En ese segundo programa, también hay una referencia, más breve, a la trayectoria militante de Lula que menciona su detención durante la dictadura y lo describe como fundador del PT.

${ }^{31}$ La referencia se formula a través de frases como "Dilma inicia su lucha contra la dictadura, su lucha por un Brasil mejor" o "Dilma enfrentó la dictadura". Pero las fotos que acompañan esta frase no son de ella sino de movilizaciones, de represión policial y de la prisión Tiradentes, donde permaneció detenida. Es decir, no hay ni una sola foto, en todo el HGPE de 2010, de Dilma como militante juvenil o presa política. En 2014, en cambio, esas imágenes tendrían un rol central.

32 Recién en el segundo turno, en tres de los programas, volvería a hacerse una alusión a la militancia de Dilma durante la dictadura, pero nunca con fotos de ella misma sino de movilizaciones.

33 Desde un análisis del discurso de Dilma en el HGPE de 2010, aunque tomando sólo uno de los programas (17/10/10), Jucá y Chaves (2015) afirman, de modo similar, que Dilma procuró deshacer la imagen previa que circulaba, de militante armada, redelineando su postura, tono de voz, gestos y expresiones faciales.

34 Aunque desde un estudio con otro diseño metodológico, basado en el análisis del discurso, y centrado más bien en el modo de construcción de la imagen positiva de Dilma, Trevisol y Perin (2014) sostienen, de modo similar, que en la campaña de 2014 "el pasado de Dilma Rousseff, que remite al hecho de la militancia política, se constituyó como punto interesante para que el equipo de publicitarios trabajara en la campaña. Esos factores, en vez de ocultados, fueron expuestos a favor de la candidata, colocándola como una mujer con garra, fuerte, que lucha a favor del pueblo brasilero" (Trevisol y Perin, 2014, p. 11). En contraste, Panke (2011) señala cierto uso de la militancia política de Dilma en el HGPE de 2010, en una operación de articulación de los perfiles disímiles de Lula (de origen humilde) y Dilma (sin ese origen) a través de un eje en común: la militancia política. Cabe discutir este argumento tomando en cuenta que la militancia política de Dilma sólo fue mencionada (brevemente) en los programas 1 y 2 de 2010, mientras que fue suprimida, para el resto del HGPE de esa elección, del segmento biográfico en blanco y negro, que, en adelante, como vimos, se limitó a su carrera en la función pública.
} 
La primera es una fotografía suya en blanco y negro a punto de declarar ante un tribunal militar. Allí Dilma aparece seria, casi de perfil, como lista para enfrentar a los hombres que se están tapando la cara para no aparecer en la imagen. Además de acompañar el cierre del jingle "Corazón valiente" en numerosos HGPE de 2014, esa foto es usada en el programa $24^{\circ}$ ( $y$ en, por lo menos, otros cinco posteriores), en un segmento sobre un encuentro de Dilma en Brasilia con dirigentes de organizaciones juveniles. Allí, sentados todos en el living del Planalto, una de las invitadas, la presidenta de la Unión Nacional de Estudiantes (UNE), interviene en la conversación diciéndole a Dilma: "Su figura inspira a la juventud. Cuando vemos aquella fotografía suya en la que le toman declaración en la dictadura [el HGPE muestra aquí la fotografía de Dilma ante el tribunal], aquello es un corazón valiente, aquello es el símbolo y es el corazón con el cual nos identificamos".

La segunda foto es una de Dilma después de ser detenida. Una suerte de foto de prontuario, sosteniendo un cartel con un número, que la muestra joven y de anteojos. Esa imagen fue convertida para la campaña de 2014 en un dibujo con su cara en blanco y negro, y la silueta de su pelo y su ropa rellenadas con pequeñas fotos de la dictadura (documentos de su detención, escenas de represión, e incluso la foto de la declaración a la que aludimos antes). Ese retrato asume un lugar medular en la campaña oficial y en la estética del HGPE de 2014. Es reproducido en el jingle "Corazón Valiente" y spots que lo incluyen. Aparece, asimismo, como gigantografía en la escenografía de actos de campaña proyectados en los programas. También, como imagen detrás de la cual dirigentes y artistas graban su testimonio de apoyo a Dilma. E incluso, como bandera gigante que el público despliega por encima de sus cabezas ${ }^{35}$.

Otros dos recursos que aparecen en el HGPE de 2014 ponderando directa o indirectamente la trayectoria militante de Dilma durante la dictadura son, por un lado, las alusiones a su detención y tortura en discursos de ella misma y de Lula en actos de campaña proyectados en los programas ${ }^{36}, \mathrm{y}$, por otro, el uso reiterado del término "lucha" por parte de la candidata en sus apelaciones en el HGPE. Esa palabra, que había estado virtualmente ausente en 2010, y que constituye una alusión implícita a la militancia política, se vuelve un término insistentemente repetido por la candidata en el HGPE $2014^{37}$.

\footnotetext{
35 En los spots argentinos la referencia a la militancia juvenil de los propios dirigentes es escasa e indirecta, en alusión a Néstor Kirchner. En el spot "La fuerza de él", CFK dice en off que recuerda "esa raza de políticos, como era Néstor, que, sin medir costos y consecuencias, se lanzaba a la batalla [...] porque tenía ideas, convicciones".

36 A modo de ejemplo, en un segmento de un acto de campaña que el HGPE reproduce, luego de imitar burlonamente a Aécio Neves, el candidato opositor, Lula le dice a la multitud, exaltado: "¿Quién es esa Dilma? iEsa chica que fue presa a los 20 años porque quería democracia en este país! ¿Dónde estaba Aécio cuando Dilma estaba presa luchando por la democracia?". O también, la voz en off de Dilma, con imágenes de ella en actos, afirma: "Luché contra la dictadura, vencí a la tortura, vencí al cáncer [cáncer linfático sufrido en 2009]".

37 Por ejemplo, en el programa $41^{\circ}$ (segundo turno, 9/10/14), la voz en off de Dilma que acompaña imágenes de actos de campaña dice: "La lucha continúa. Invito a todos ustedes a que tengan fe en Brasil, que participen de esta lucha con nosotros. Una lucha que, sin duda, será una vez más, victoriosa, porque es la lucha de la mayoría del pueblo brasilero, porque es la lucha de [y nombra diferentes actores sociales]". En el programa $24^{\circ}$, en el encuentro en el living del Planalto con los dirigentes juveniles, Dilma les dice: "Nosotros tenemos que tener la capacidad de luchar. Si vos tenés la capacidad de luchar por lo que creés, una parte del camino
} 
Incluso, en la cobertura del encuentro ya mencionado con dirigentes juveniles (programa $24^{\circ}$ ), la referencia de Dilma a su propia militancia en la dictadura explicita algo impensable para la campaña de 2010: su extracción política socialista y revolucionaria durante aquel período. En el encuentro, Dilma les dice a sus invitados:

\begin{abstract}
Hay un nivel de creencia que nosotros tenemos en la juventud, que es una cosa que justifica que uno esté en el mundo [...] yo justifico mi presencia en el mundo por aquello en lo que creo. Yo pensaba que la revolución socialista dependía de que yo militara 24 horas por día. Y si paraba de militar 24 horas por día, la revolución socialista no se daba. Vos llegabas, te levantabas a la mañana y decías "yo soy un revolucionario. Mañana está todo resuelto" [risas de los presentes]. Yo creo que tienen un poco de eso las manifestaciones de junio. Por eso las encontré tan interesantes (el resaltado es nuestro) ${ }^{38}$.
\end{abstract}

\title{
Conclusiones
}

A partir de la propuesta en este trabajo de análisis y observación de las cuatro campañas presidenciales de televisión de Cristina Fernández de Kirchner (CFK) y de Dilma Rousseff (DR) para 2007 y 2011, y 2010 y 2014, respectivamente, se ha realizado una interpretación comparativa doble -diacrónica y entre ambos casos nacionales- en torno a las modalidades de visualización de la militancia oficialista en las campañas de ambas candidatas. En el marco de una investigación más amplia sobre la transformación del vínculo militante, hemos examinado el peso visual y modalidades de representación simbólica de esas bases de sustentación activa de los gobiernos kirchneristas y del PT.

El análisis del material empírico nos permite afirmar que las campañas televisivas de DR y CFK en 2014 y 2011, respectivamente, asignaron un mayor peso visual a la militancia y la movilización orgánica que las anteriores. Dado ese significativo contraste en términos del lugar audiovisual asignado a la militancia oficialista en las campañas de 2007 (Argentina) y 2010 (Brasil), por un lado, y las campañas de 2011 (Argentina) y 2014 (Brasil), por otro, hemos dedicado una mayor atención y espacio del análisis en el artículo a estas últimas dos, con el objetivo de dar cuenta, de modo detallado, de las características específicas con las que hizo aparición allí ese colectivo militante, y cómo se hizo referencia indirectamente al activismo a través de las menciones a la trayectoria de la propia Dilma Rousseff.

está hecho. Dependen de vos, depende de vos [señalando a cada uno], depende de cada uno de nosotros cambiar el país".

38 Cabe aclarar, sin embargo, que este fragmento sería repetido en el HGPE sólo una vez más (programa $25^{\circ}$ ). En adelante, la cobertura del encuentro volvería a ser incluida en programas posteriores con numerosas alusiones a la militancia y la movilización, pero sin mencionar ya la "revolución socialista" o el carácter "revolucionario". 
Como balance o síntesis del análisis realizado, para el caso argentino, podemos afirmar que, mientras la campaña de 2007 privilegió, de algún modo, exhibir a ciudadanos comunes y el modo en que sus respectivas vidas habían sido transformadas por las políticas del gobierno kirchnerista -estrategia similarmente esbozada en la primera campaña de Dilma en 2010- en 2011, en cambio, los avances de los gobiernos kirchneristas aparecían personificados o representados a través de figuras militantes. A partir de la consigna "la fuerza de...", el "país" sería ilustrado a través del colectivo militante escenificando un acto de campaña; los "jóvenes" serían jóvenes activistas aclamando y arengándose mutuamente; y las "amas de casa" aparecen ilustradas por mujeres movilizándose y portando iconografía militante.

Como vimos a lo largo del artículo, en Brasil, la proyección de imágenes de actos organizados y apoyos militantes u orgánicos es un elemento presente tanto en 2010 como en 2014. Sin embargo, el salto cualitativo y cuantitativo de este elemento hacia 2014 es contundente. Se les dedica más tiempo a estos segmentos en el HGPE, se los intercala más a lo largo de cada programa y también, en alguna medida, acaban sustituyendo a otros dos recursos que tenían más presencia en 2010: la exhibición de encuestas de opinión y los testimonios de personas "comunes" (por ejemplo, de beneficiarios de programas sociales). Pero, además, el HGPE de 2014 introduce una modalidad específica de representación visual de la militancia que en 2010 había estado virtualmente ausente, y que, en 2014, en cambio, llega a definir la propia línea estética central de la campaña: la ponderación y reivindicación de la trayectoria de Dilma como militante durante la dictadura militar.

A la hora de interpretar el contraste diacrónico planteado, los contextos o coyunturas políticas pueden contribuir a dilucidar los sentidos expresados en esas campañas que optaron por un despliegue visual de la intermediación militante.

Tanto en el caso de CFK para su segunda candidatura en 2011, como en el caso de DR en 2014 ya no era necesario, por supuesto, hacer una campaña orientada a la presentación o introducción de ambas candidatas, como sí había sucedido (aunque más en el caso brasilero que en Argentina) en las campañas anteriores (2007 y 2010). Tras cuatro años de mandato, ambas contaban ya con suficiente nivel de conocimiento en la ciudadanía para apelar a otro enfoque de campaña con vistas a su reelección. Pero, además, cabría situarnos en dos episodios que marcaron, tal vez, un punto de inflexión en el escenario político de cada país, y podrían, por ello, haber sido influyentes en el carácter de las campañas que tendrían lugar sólo un año después: en Argentina, la muerte de Néstor Kirchner en octubre de 2010; y, en Brasil, las movilizaciones de junio de 2013.

En el caso argentino, la muerte de Néstor Kirchner en 2010, cuya jornada de exequias exhibió multitudes de militantes movilizados (además de ciudadanos no organizados), contribuyó a acelerar el crecimiento sideral de La Cámpora y, en menor proporción, de otras agrupaciones militantes que venían surgiendo o cobrando visibilidad especialmente desde el conflicto entre el gobierno y las entidades agropecuarias en 2008. 
La muerte de Kirchner en 2010 inauguraba, de algún modo -y la campaña por la reelección de CFK en 2011 continuaba- un período en el que el kirchnerismo reposicionó a la militancia oficialista ante la opinión pública, asignándole una considerable visibilidad y referencias en los discursos o apelaciones presidenciales a la militancia que no había tenido en 2007. Y ello se materializó o alcanzó un clímax con los denominados Patios Militantes de 2014 y 2015, actos cerrados en los patios de la Casa de gobierno, en los que, más que el consenso popular, lo que parecía mostrarse (por televisión, luego de la cadena nacional de algún acto de gobierno) y ostentarse como propio era un sustento militante, que, de todos modos, aparecía representado como una expresión potenciada del apoyo popular. Es decir, el apoyo popular no se exponía a través de una mera imagen positiva en las encuestas o incluso un caudal electoral, sino desde la imagen de un apoyo comprometido e intenso, y hasta exhibido como distintivo del kirchnerismo. Esta suerte de operación simbólica de "la parte por el todo" se advertía con claridad en los spots electorales de 2011. En este sentido, cada uno de los spots analizados finalizaba con frases como "La Fuerza de un Pueblo" o "La Fuerza de un País" que se ilustraban con una imagen de una multitud de militantes frente a CFK agitando banderas, ovacionando, saludando a la presidenta. Ese pueblo parecía ser materializado, en el mensaje audiovisual, en el colectivo militante movilizado. Así, se ponía en escena, con un lugar preponderante, a la militancia como actor de la campaña, pero también como expresión del apoyo popular, y eventualmente electoral.

En Brasil, por su parte, la paralelización de "las calles" y "las encuestas" en la campaña televisiva no era una operación idéntica de superposición de la parte y el todo, pero sí insinuaba cierta equivalencia en la sumatoria de ambos tipos de apoyo, sugiriendo la voz en off del HGPE que la movilización militante de apoyo a Dilma se traducía en las encuestas de opinión, y viceversa. Por ejemplo, en la afirmación "iLo que las encuestas muestran, las calles lo confirman!" (23/10/10), o también, a la inversa, en "Lo que Datafolha [consultora de opinión pública] muestra, está en las calles" (27/09/14). Se colocaba, así, en el mismo plano, al potencial electorado anónimo de la candidata con los adherentes movilizados ${ }^{39}$.

En Brasil, la coyuntura a la que deberíamos atender para reflexionar sobre el considerable peso visual de la militancia en la campaña televisiva de 2014 es la de las movilizaciones masivas de 2013. Las llamadas "jornadas de junio" empezaron con un reclamo local contra el aumento del transporte público y fueron multiplicándose hasta volverse masivas, a la par de diversificarse agudamente sus consignas y composición, y transformarse, también, el tipo de cobertura que les iban dando los medios de comunicación masiva. La militancia oficialista, especialmente el PT y la CUT, enfrentaría algunas dificultades para participar de las mismas y para imprimirles una orientación.

\footnotetext{
39 De todos modos, éste fue un elemento, como vimos, más característico en 2010, cuando la evolución de la intención de voto de Dilma en las encuestas fue informada más temprano y más insistentemente que en 2014.
} 
En cierta forma, la campaña televisiva de DR en 2014 (los programas diarios del HGPE) revelaba -en ocasiones de modo implícito y otras, explícitamente- las repercusiones de las protestas de 2013 para el propio oficialismo. Ello, aunque, como vimos que argumentaba Castro (2016), la alusión a las manifestaciones de 2013 no haya tenido peso cuantitativo predominante en el HGPE en comparación con otros temas. A modo de ejemplo de esas repercusiones o coletazos, en el primer programa del segundo turno de la campaña, Dilma declaraba "entendí el mensaje de las calles y de las urnas", y luego expresaba la necesidad de perfeccionar y profundizar sus políticas de gobierno. En otros programas, se aludía tácitamente a las movilizaciones de 2013, con imágenes de las mismas y una voz en off diciendo "en los últimos años viste muchas cosas suceder en Brasil", para luego referirse a otras que "sucedieron sin que las percibieras" (presentando una sucesión de medidas del gobierno y avances sociales). En este tipo de ejemplos, la alusión de la campaña a las manifestaciones de 2013 parecía reconocer, de algún modo, el golpe que habían constituido para el gobierno y para el propio PT, que, luego de décadas de protagonizar la movilización callejera, había quedado expuesto como un destinatario (aunque indirecto aún, a diferencia de las movilizaciones posteriores de 2015 y 2016) del reclamo masivo. Pero, además, el HGPE de 2014, como vimos, incluyó referencias a las protestas de 2013 en lo que pareció una reelaboración posterior del significado de las mismas. Los fragmentos, analizados en este artículo, del encuentro de la presidenta con dirigentes juveniles en el Planalto, repetidos en varios programas, presentaban a las organizaciones presentes como "movimientos de jóvenes que fueron a las calles en las manifestaciones de junio, para defender más avances". Con ello, se asimilaba a las manifestaciones como un impulso al gobierno para seguir avanzando más que como impugnación de los deficientes servicios públicos (transporte, salud etc.); se procuraba una asociación con las mismas; y hasta se produjo una suerte de resignificación del rol que en ellas había tenido la militancia oficialista, insertándola retroactivamente en un lugar más protagónico.

Las coyunturas mencionadas resultan más que sugerentes para poder pensar por qué y a través de qué modalidades las campañas televisivas de 2011 en Argentina y 2014 en Brasil representaban visualmente de manera recurrente a la militancia y el activismo.

Dolores Rocca Rivarola - Consejo Nacional de Investigaciones Científicas y Técnicas (CONICET), Buenos Aires, Argentina; Instituto de Investigaciones Gino Germani (IIGG), Universidad de Buenos Aires (UBA), Buenos Aires, Argentina.

E-mail: <doloresrocca@gmail.com>.

Nicole Marina Moscovich - Universidad de Buenos Aires (UBA)/Universidad de Ciencias Empresariales y Sociales (UCES), Buenos Aires, Argentina.

E-mail: <nicolemoscovich@gmail.com>. 


\section{Referencias bibliográficas}

ALBUQUeRQUe, A. "Aqui você vê a verdade na tevê: a propaganda política na televisão". Publicações do Mestrado em Comunicação, Imagem e Informação II, Niterói, 1999.

. "Advertising ou propaganda? O audiovisual político brasileiro numa perspectiva comparativa". Alceu, vol. 5, n 10, p. 215-227, 2005.

ÂNGELO, V. A. "Mídia e eleições: notas sobre a cobertura jornalística da campanha presidencial de 2010 no Brasil". Anais do $8^{\circ}$ Encontro da ABCP, Gramado, RS, 2012.

ANNUNZIATA, R. ¿Hacia un nuevo modelo de lazo representativo? La representación de proximidad en las campañas electorales de 2009 y 2011 en Argentina. In: CHERESKY, I.; ANNUNZIATA, R. (comp.). Sin programa, sin promesa. Liderazgos y procesos electorales en Argentina. Buenos Aires: Prometeo, p. 45-87, 2012.

Aquino, Z. G. O.; LUQUES, S. U. "Propaganda político-eleitoral - Um discurso em busca de legitimidade". Linha d'Água, vol. 2, n²5, p. 131-145, 2012.

ARIAS, M. F. "Liderazgo carismático y el ascenso de Menem a la presidencia de la nación en 1989". Colección, vol. 3, p. 31-35, 1996.

BACHINI, N. "As cibercampanhas no Brasil: uma análise dos Twitters de Dilma, Serra e Marina em 2010". Ponto-e-vírgula, vol. 12, p. 135-164, 2013.

Bartolomeu, T. C.; Ludovice, C. A. B. "As relações dialógicas na primeira propaganda eleitoral de Dilma Rousseff em 2014". In: Ludovice, C. A. B.; Ferreira, F. A.; Pernambuco, J. (orgs.). Anais do VI Selinfran, Seminário de pesquisa em linguística da Unifran "Linguística do texto e do discurso: movimentos do sentido". São Paulo: Universidade de Franca, 2015.

BORBA, F. "A influência das campanhas nas eleições presidenciais. O papel da mídia". Civitas, vol. 2, $n^{\circ} 2$, p. 300-322, 2008.

. "O uso estratégico das inserções nas eleições presidenciais brasileiras". Revista Compolítica, vol. 2, n², p. 94-120, 2012.

BRADER, T. "Striking a responsive chord: how political ads motivate and persuade voters by appealing to emotions". American Journal of Political Science, vol. 49, n² 2, p. 388-405, 2005.

CARVALHO, L. B. "Construção da imagem e midiatização: estudo das imagens de Lula nas campanhas presidenciais". Trabalho de conclusão de curso. Habilitação em Relações Públicas. Departamento de Comunicação, Universidade Federal de Rio Grande do Sul, Porto Alegre, 2011.

CASTRO, F. E. "As manifestações brasileiras de 2013 sob a ótica do HGPE dos candidatos a presidente do Brasil em 2014". Dissertação de Mestrado em Comunicação. Universidade Federal do Paraná, Curitiba, 2016.

Cervi, E. U.; Massuchin, M. G.; TAVAres, C. Q. "Agenda da mídia, dos políticos e do público na campanha eleitoral de 2010". Revista Debates, vol. 6, n 1, p. 237-261, 2012.

CHERESKY, I. Los desafíos democráticos en América Latina en los albores del siglo XXI. In: CHERESKY, I. (comp.). Elecciones presidenciales y giro político en América Latina. Buenos Aires: Manantial, p. $19-49,2007$. 
DOLORES ROCCA RIVAROLA; NICOLE MARINA MOSCOVICH

Cingolani, G.; Fernández, M. "Televisión y política: espacio público, puestas en escena y regímenes de visibilidad". Oficios Terrestres, año XVI, n²5, p. 37-49, 2010.

D'AlesSANDRO, M. "¿Qué es la personalización de la política? Algunos hallazgos en los medios gráficos, 1983-1995". Revista Argentina de Ciencia Política, Buenos Aires, n 7-8, p. 73-93, 2004.

Political advertising in Argentina. In: Holtz-BACHA, C.; JUST, M. R. (eds.). Routledge handbook of political advertising. New York: Routledge, p. 75-86, 2017.

DIAS, M. R. "Nas brumas do HGPE: a imagem partidária nas campanhas presidenciais brasileiras (1989 a 2010)". Opinião Pública, vol. 19, n 1, p. 198-219, 2013.

FERNANDES, C. M. "As representações midiáticas de Dilma Rousseff no cenário político brasileiro". Aurora, Revista de Arte, Mídia e Política, vol. 5, n 14, p. 69-85, 2012.

FERNANDES, C. M., et al. "Campanha permanente de Dilma Rousseff: uma análise da comunicação governamental e das estratégias eleitorais". Mediaciones Sociales, nº 15, p. 81-100, 2016.

FLEISCHER, D. Análise político das perspectivas da reforma política no Brasil, 2005-2006. In: FleISCHER, D., et al. (orgs.). Reforma política: agora vai? Cadernos Adenauer, vol. VI, n 2 , Rio de Janeiro: Fundação Konrad Adenauer, p. 13-38, set. 2005. Disponível em:

<http://www.kas.de/wf/doc/9796-1442-5-30.pdf>. Acesso em: 8 mar. 2018.

FREITAS, V. G. "Imagens de mulher e agenda de gênero na reta final da campanha da primeira presidenta do Brasil". Revista Ártemis, vol. XVI, nº 1, p. 186-203, 2013.

García BeAudoux, V.; D 'AdAmo, O. "Campañas electorales y sus efectos sobre el voto. Análisis de la campaña electoral presidencial 2003 en Argentina". Psicología Política, n 24, p. 7-25, 2004.

"Comunicación política y campañas electorales. Análisis de una herramienta comunicacional: el spot televisivo". Polis, vol. 2, n² 2, p. 81-111, 2006.

GouVÊA, G. N. "Imaginário social, mito e narrativas jornalísticas. As representações sobre mulheres políticas e militantes de esquerda na construção discursiva sobre a presidente Dilma Rousseff". Tese de mestrado em Comunicação, Universidade de Brasília, Brasília, 2014.

Grosman, J. "El discurso de campaña de Cristina Fernández de Kirchner". Tesis de licenciatura en Comunicación. Departamento de Ciencias Sociales, Universidad de San Andrés, Victoria (provincial de Buenos Aires), 2012.

Gunther, R.; DiAmond, L. "Species of political parties: a new typology". Party Politics, vol. 9, n 2, p. 167-199, 2003.

IAZzetTA, O. Bajo el signo del desequilibrio político. In: Cheresky, I.; AnnunziatA, R. (comp.). Sin programa, sin promesa. Liderazgos y procesos electorales en Argentina. Buenos Aires: Prometeo, p. 277-306, 2012.

Johnston, A.; KAID, L. L. "Image ads and issue ads in U.S. presidential advertising: using videostyle to explore stylistic differences in televised political ads from 1952 to 2000". Journal of Communication, vol. 52, no 2, p. 281-300, 2002.

JucÁ, C. M.; ChAVES, A. S. "A reconstrução do ethos discursivo da candidata Dilma Rousseff durante a campanha presidencial de 2010". Revista Philologus, año 21, nº 63, p. 284-303, 2015. 
KAID, L. L., et al. "Television news and presidential campaigns. The legitimization of televised political advertising". Social Science Quarterly, vol. 74, n², p. 274-285, 1993.

KNoblauch, H.; TUma, R.; SChnettler, B. Video analysis and videography. In: Flick, U. (ed.). The Sage handbook of qualitative data analysis. London: Sage, p. 435-449, 2014.

LEAL, P. R. F.; VieIRA, M. B. M. H. "O fenômeno da personalização da política: evidências comunicacionais das campanhas de Dilma e Serra em 2010". Teoria e Cultura, vol. 4, n 1-2, p. 4150, 2009.

LIMA, A.; PANKE, L. "Imagem e desqualificação: o caso de Dilma Rousseff nas eleições presidenciais brasileiras de 2014". Em Debate, vol. 8, n 5, p. 8-16, 2016.

LIMEIRA, T. M. V.; MAIA, T. "Comunicação política e decisão de voto: o que as pesquisas revelam". Ponto-e-vírgula, vol. 8, p. 42-55, 2010.

LUCHESI, R. M. "Um estudo das campanhas de Dilma Rousseff em 2010 e 2014 no HGPE da TV". Dissertação de mestrado em Ciência Política, Universidade Federal de São Carlos, São Carlos, 2016.

MANCuso, W. P. A reforma política e o financiamento das campanhas eleitorais. Em: IANONI, M. (org.). Reforma política democrática. Temas, atores e desafios. São Paulo: Fundação Perseu Abramo, p. 83-103, 2015.

MANIN, B. Metamorfosis de la representación. In: Dos SANTOS, M. R. (coord.). ¿Qué queda de la representación política? Caracas: Clacso-Nueva Sociedad, p. 9-41, 1992.

MARQUES, F. P.; SAMPAIO, R. "Internet e eleições 2010 no Brasil: rupturas e continuidades nos padrões midiáticos das campanhas políticas online". Revista Galáxia, São Paulo, n², p. 208-221, 2011.

MARques, J. E. D. C. "Juventude do Partido dos Trabalhadores: institucionalização e militância juvenil". Goiânia. Tese para o Programa de Pós-Graduação em Sociologia. Faculdade de Ciências Sociais, Universidade Federal de Goiás, 2016.

MARTINS, J. M. L. "Era FHC x Era Lula: a disputa simbólica no horário eleitoral de 2010". Revista de Discentes de Ciência Política da Ufscar, vol. 2, nº 1, 69-93, 2014.

MARQUES, L. M. "O papel da memória na produção dos sentidos no HGPE de Dilma Rousseff". Entrepalavras, año 2, vol. 2, nº esp., p. 60-82, 2012.

MAssuchin, M. G.; TAVARES, C. Q. "Estratégias eleitorais online: os padrões de campanha nas páginas dos candidatos durante as eleições de 2014 no Brasil". Teoria e Pesquisa: Revista de Ciência Política, São Carlos, vol. 25, n 1, p. 7-42, 2016.

Montero, A. S. "Puesta en escena, destinación y contradestinación en el discurso kirchnerista (Argentina, 2003-2007)". Discurso \& Sociedad, vol. 3, n² 2, p. 316-347, 2009.

MoreirA, T. L.; MARTins T. F. "Ativismo, comunicação e política: a voz das ruas em 2013 e o discurso político no HGPE em 2014". Anais do IX Simpósio Nacional ABCiber, PUC, São Paulo, 2016.

Moreira Salles, J. Entreatos. Documental, Brasil, Vídeo Filmes, 2004.

MurARo, H. "La publicidad (y la política de la publicidad) en la Argentina". Diálogos de Comunicación (Felafacs), n²7, 1990. 
Nicolau, J. "Como aperfeiçoar a representação proporcional no Brasil". Cadernos de Estudos Sociais e Políticos, vol. 4, n 7, p. 219-239, 2015.

NorRIS, P. Digital divide: civic engagement, information poverty, and the internet worldwide. Cambridge: Cambridge University Press, 2001.

. "Tuned out voters? Media impact on campaign learning". Political Communication, vol. 1, p. $72-100,2008$.

OliVeirA, A. "O marketing político como objeto de estudo da ciência política. Teoria, conceito e instrumentos". Anais $5^{\circ}$ Congresso de Compolítica, Associação Brasileira de Pesquisadores em Comunicação e Política. Curitiba, 8-10 maio, 2013.

OliveirA, L. A.; MARTInS, T. F. "As estratégias retóricas utilizadas por Dilma e Serra no primeiro turno do HGPE de 2010". Revista Científica da Faminas, vol. 9, n 3, p. 94-113, 2013.

Oliveira, L. A.; MARTins, T. F.; LeAL, P. R. F. "As estratégias midiáticas de Dilma Rousseff (PT) na eleição presidencial de 2014". E-COM, vol. 8, p. 1-15, 2015.

Palermo, V.; Novaro, M. Política y poder en el gobierno de Menem. Buenos Aires: Norma, 1996.

PANKE, L. "Análise comparativa entre as campanhas eleitorais dos brasileiros D. Rousseff e L. I. Lula da Silva". ComHumanitas, año 3, vol. 3, n 3, p. 39-47, 2011.

PANKE, L., et al. "O que os candidatos à presidência do Brasil falaram nos programas do HGPE nas últimas eleições". Anais do IV Encontro de Compolítica, Uerj, 13-15 abril, 2011.

Parzianello, S. R. B. "O discurso da mudança de Aécio Neves e Dilma Rousseff: uma análise da prática retórica entre diferentes, no retorno para o segundo turno às eleições de 2014". Em Tese, vol. $13, \mathrm{n}^{\circ} 1$, p. 6-18, 2016.

PIRES, T. M. C. C. "A construção da imagem política de Dilma Rousseff como mãe do povo brasileiro". Revista Debates, vol. 5, n 1, p. 139-162, 2011.

PousAdela, I.; Cheresky, I. La incertidumbre organizada. Elecciones y competencia política en Argentina (1983-2003). In: ChereSKY, I.; PousAdelA, I. (eds.). El voto liberado. Elecciones 2003: perspectiva histórica y estudio de casos. Buenos Aires: Biblos, p. 13-33, 2004.

Quirós, J. Militante. In: Vommaro, G.; Adelstein, A. (coords.). Diccionario del léxico corriente de la política argentina. Palabras en democracia (1983-2013). Polvorines: UNGS, 2014.

Ribeiro, P. J. F. "Campanhas eleitorais em sociedades midiáticas: articulando e revisando conceitos". Revista de Sociologia e Política, vol. 22, p. 25-43, 2004.

. "Dos sindicatos ao governo: a organização nacional do PT de 1980 a 2005". Tese doutorado em Ciência Política. Universidade Federal de São Carlos, São Carlos, 2008.

Rocca Rivarola, M. D. "En torno al líder: relaciones y definiciones de pertenencia dentro de los conjuntos oficialistas de Luiz Inácio Lula da Silva (2002-2006) y Néstor Kirchner (2003-2007)". Tesis de doctorado en Ciencias Sociales. Universidad de Buenos Aires, Buenos Aires, 2011.

"De las jornadas de junho al impeachment sem crime: protestas, militancia oficialista y crisis política en Brasil (2013-2016)". VI Jornadas de Estudios Políticos de la Universidad Nacional de General Sarmiento, Polvorines, Provincia de Buenos Aires, 2016. 
REPRESENTACIÓN VISUAL Y SIMBÓLICA DE LA MILITANCIA EN LAS CAMPAÑAS ELECTORALES DE KIRCHNER E ROUSSEFF

. La militancia kirchnerista. Tres momentos del compromiso activo oficialista (2003-2015). In: Pucciarelli, A.; CAstellani, A. (coords.). Los años del kirchnerismo. La disputa hegemónica tras la crisis del orden neoliberal. Buenos Aires: Siglo XXI, p. 319-347, 2017a.

"Saudade do partido: referencias nostálgicas entre militantes de las bases de sustentación de los gobiernos argentinos y brasileros (2003-2015)". Revista de Sociologia e Política, vol. 25, n62, p. 37-61, 2017b.

RuBim, A. A. C. "Cultura e política na eleição de 2002: as estratégias de Lula presidente". Anais do XII Encontro Anual da Associação Nacional dos Programas de Pós-Graduação em Comunicação (Compós), Recife-PE, 2003.

SARTORI, G. Videopolítica. Medios, información y democracia de sondeo. Madrid: F.C.E., 2003.

SILVA, E. C. S.; LEAL, P. R. F. "Estratégias de comunicação da campanha eleitoral da candidata Dilma Rousseff: do anonimato à presidência". Anais do XXXIV Congresso Brasileiro de Ciências da Comunicação, Sociedade Brasileira de Estudos Interdisciplinares da Comunicação. Recife, 2011.

SLImovich, A. "Política y redes sociales en Argentina. El caso de los candidatos presidenciales de 2011 en Twitter". Signo y Pensamiento, vol. 35, n 68, p. 86-100, 2016.

SOPRANO, G. "El marketing político y la dinámica de las facciones de un sublema en una campaña electoral municipal". Terceras Jornadas de Sociología de Universidad Nacional de La Plata, La Plata, 10-12 de diciembre, 2003.

TAVARES, C. Q. "'Para presidente vote na gente'. As personalidades presentes nos programas do PT e PSDB veiculados no horário eleitoral de 2002, 2006 e 2010". Dissertação de mestrado em Ciências Sociais Aplicadas. Universidade Estadual de Ponta Grossa, 2013.

Telles, H. S.; PIRes, T. M. C. C. "Criador e criatura: Petismo e lulismo nas retóricas discursivas do HGPE de Dilma Rousseff". Anais do $5^{\circ}$ Congresso de Compolítica, Associação Brasileira de Pesquisadores em Comunicação Política. Curitiba, 8-10 maio, 2013.

Trevisol, M. G.; Perin, C. "Discurso ideológico e persuasão: análise da campanha eleitoral de Dilma Rousseff/2014". Anais do XVI Congresso de Ciências da Comunicação na Região Sul, Sociedade Brasileira de Estudos Interdisciplinares da Comunicação. Joinville, 4-6 de junho, 2014.

VÁZQUEZ, M. "En torno a la construcción de la juventud como causa pública durante el kirchnerismo: principios de adhesión, participación y reconocimiento". Revista Argentina de Estudios de Juventud, vol. $1, \mathrm{n}^{\circ} 7,2013$.

VeIGA, L. F. "Em busca das razões para o voto: o uso que o eleitor faz da propaganda política". Contracampo, vol. 7, nº 0, p. 183-208, 2002.

VenturA, A. S. "Argumentación y discurso político en Twitter. Análisis de la campaña presidencial argentina 2011". Aposta. Revista de Ciencias Sociales, n 69, p. 39-66, 2016.

VERÓN, E. Mediatización de lo político. Estrategias, actores y construcción de los colectivos. In: Gauthier, G.; Gosselin, A.; Mouchon, J. (comp.). Comunicación y política. Buenos Aires: Gedisa, p. 220-236, 1998.

Espacios mentales. Buenos Aires: Gedisa, 2002. 
Vitale, M. A.; Maizels, A. L. "El discurso electoral de Cristina Fernández de Kirchner (2007). Un caso de ethos híbrido no convergente". Linguagem em (Dis)curso, vol. 11, n² 2, p. 337-360, 2011.

Vommaro, G. Cuando el pasado es superado por el presente. Las lecciones presidenciales en 1983 y la construcción de un nuevo tiempo político en la Argentina. In: Pucciareli, A. (coord.). Los años de Alfonsín ¿El poder de la democracia o la democracia del poder? Buenos Aires: Siglo XXI, p. 245-288, 2006.

WAISBORD, S. "A sign of the times: television and electoral politics in Argentina, 1983-1989". Kellogg Working Paper Series, n 190, 1993.

\section{Anexos - Material empírico utilizado}

\section{1- Argentina}

Selección de 38 spots televisivos de 2007 y 2011. Piezas de 50 segundos a tres minutos de duración.

Elecciones de 2007

11 spots: "Dolores Argentina", "¿Qué es el FMI?", "Abuelo", "Recuperar la dignidad del trabajo", "Silencio", "Derechos Humanos","Inflación", " La concertación", "Recursos Naturales", "No a la impunidad", "Imágenes históricas, peronistas/radicales. Cristina, Cobos y vos".

\section{Elecciones de 2011}

Elecciones PASO:

12 spots, emitidos entre julio y agosto de 2011.

Nombres: "La Fuerza de la Vida", "La Fuerza de La Ciencia", "La Fuerza de la Dignidad", "La Fuerza de la Igualdad", "La Fuerza de La Inclusión", "La Fuerza de la Producción", "La Fuerza de La Verdad", "La Fuerza de los Jóvenes", "La Fuerza Del Futuro", "La Fuerza de Él", "La Fuerza del Amor", "Fuerza Argentina. Cristina Kirchner Presidenta".

Elecciones generales:

15 spots, emitidos entre septiembre y octubre de 2011.

Nombres: "La Fuerza de la Educación", "La Fuerza de Cecilia" (Científica), "La Fuerza de Brian (atleta)", "La Fuerza de la Alegría", "La Fuerza de la Empresa", "La Fuerza del Crecimiento", "La Fuerza de Atilio" (Trabajador en Astillero), "La Fuerza de Victoria (Montenegro, nieta recuperada)", "La Fuerza de Ariel", "La Fuerza de los Jóvenes", "La Fuerza de Jésica" (Plan Procrear), "La Fuerza de Federico" (técnico computación), "La Fuerza de Haydeé" (jubilada), "La fuerza de Elena" (TV digital), "La fuerza de la unión".

\section{2- Brasil}

La totalidad de los programas del Horário Gratuito de Propaganda Eleitoral (HGPE) emitidos en 2010 y 2014. Programas de entre 10 y 11:30 minutos de duración cada uno. Emisión diaria (tarde y noche), para la campaña de Dilma Rousseff, primero y segundo turno.

Elecciones de 2010

Campaña primer turno electoral: 17/08/10 al 30/09/10 - 37 programas

Segundo turno: $8 / 10 / 10$ al 29/10/10 - 18 programas

Elecciones de 2014

Primer turno: 19/08/14 al 02/10/14 - 40 programas

Segundo turno: 09/10/14 al 24/10/14 - 30 programas 
REPRESENTACIÓN VISUAL Y SIMBÓLICA DE LA MILITANCIA EN LAS CAMPAÑAS ELECTORALES DE KIRCHNER E ROUSSEFF

3- Fotos citadas de la campaña de 2014 (Brasil) y selección de capturas de pantalla de spots de 2011 (Argentina)
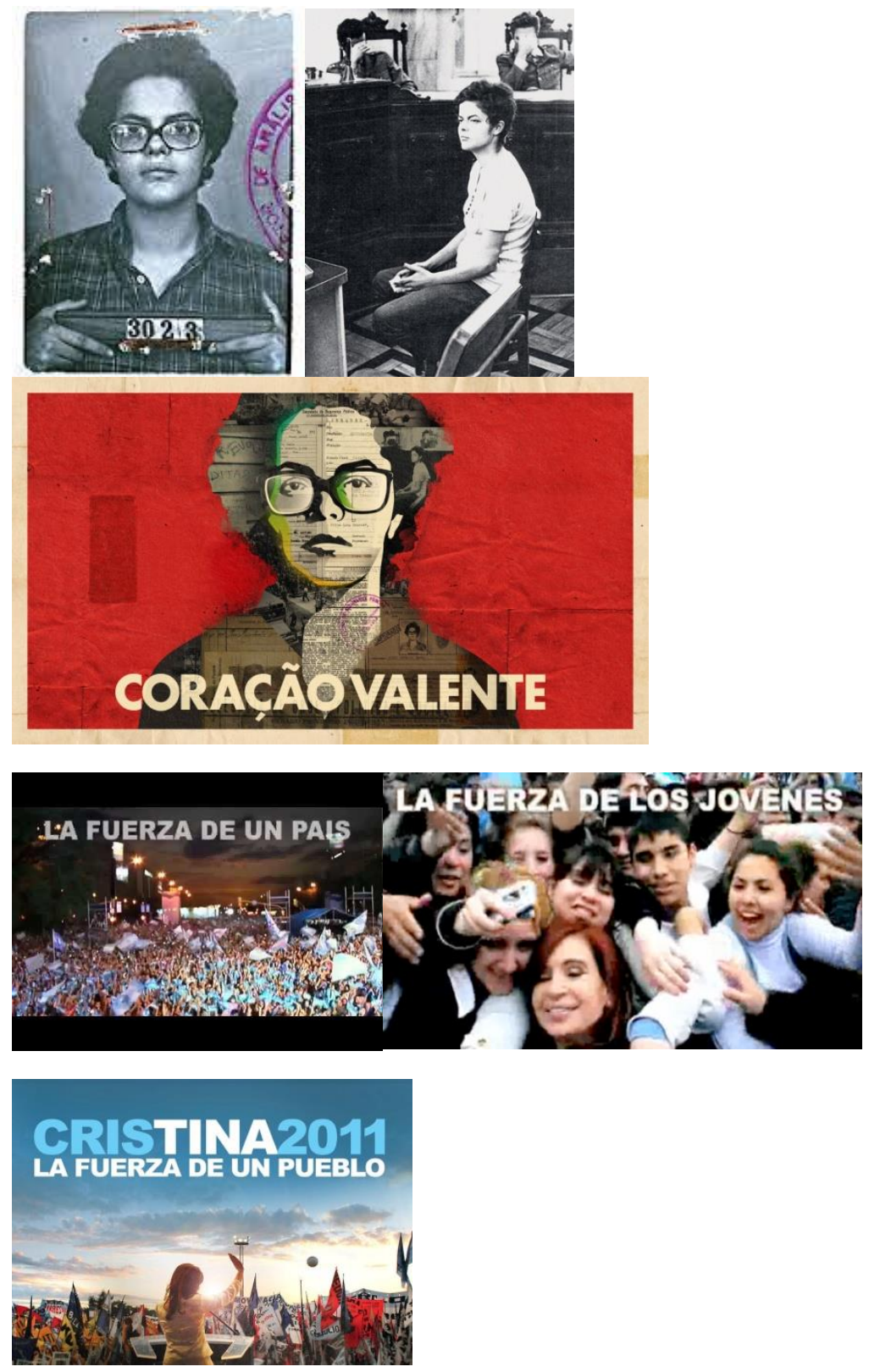


\section{Resumen}

Representación visual y simbólica de la militancia en las campañas electorales de Cristina F. Kirchner (2007 y 2011) y Dilma Rousseff (2010 y 2014)

El trabajo se propone interpretar de modo comparativo el lugar visualmente asignado en las campañas electorales de Cristina Fernández de Kirchner (2007 y 2011) y Dilma Rousseff (2010 y 2014) a la militancia oficialista en tanto colectivo movilizado y sustento organizado. Ello, luego de sucesivas campañas que privilegiaron una imagen diferente: la del candidato en un vínculo directo, y sin mediaciones, con la ciudadanía. El material empírico relevado se compone de una selección de spots argentinos y la totalidad de los programas electorales del HGPE (Horário Gratuito de Propaganda Eleitoral) en Brasil. A partir del análisis cualitativo de contenido de la propaganda electoral, se argumentará una mayor jerarquización visual del colectivo militante en las campañas de 2011 (Argentina) y 2014 (Brasil), respecto de las dos anteriores (2007 y 2010). Y, para el caso brasilero, asimismo, se postula la introducción en la campaña de 2014 de un segundo modo de representación de la militancia, a través de referencias a la trayectoria de Dilma como militante juvenil durante la dictadura militar.

Palabras clave: militancia; campaña electoral; Dilma Rousseff; Cristina Kirchner

\section{Resumo}

Representação visual e simbólica da militância nas campanhas eleitorais de Cristina F. de Kirchner (2007 e 2011) e Dilma Rousseff (2010 e 2014)

O artigo propõe uma interpretação comparativa sobre o lugar visualmente atribuído nas campanhas eleitorais de Cristina Fernández de Kirchner (2007 e 2011) e Dilma Rousseff (2010 e 2014) à militância pró-governo como um coletivo mobilizado e uma sustentação organizada. Isso, depois de sucessivas campanhas que privilegiaram uma imagem diferente: aquela do candidato em uma ligação direta, e sem mediações, com a cidadania. O levantamento de material empírico consiste em uma seleção de spots na Argentina e de todos os programas eleitorais do HGPE (Horário Gratuito de Propaganda Eleitoral) no Brasil. A partir da análise de conteúdo qualitativa da propaganda eleitoral, observa-se uma maior hierarquização visual do coletivo militante nas campanhas de 2011 (Argentina) e 2014 (Brasil), em comparação com as duas anteriores (2007 e 2010). E, para o caso brasileiro, o artigo destaca a introdução na campanha de 2014 de um segundo modo de representação da militância, através de referências à trajetória de Dilma como ativista juvenil durante a ditadura militar.

Palavras-Chave: militância; campanha eleitoral; Dilma Rousseff; Cristina Kirchner

\section{Abstract}

Visual and symbolic representation of activism in Cristina F. de Kirchner (2007 and 2011) and Dilma Rousseff's electoral campaigns (2010 and 2014)

The paper proposes a comparative interpretation of the visual role assigned in the electoral campaigns of Cristina Fernández de Kirchner (2007 and 2011) and Dilma Rousseff (2010 and 2014) to the progovernment activists as a mobilized collective and organized support. This, after years of electoral campaigns that privileged a different image: that of the candidate directly linked with voters, without any mediation. The empirical material gathered and analyzed consists of a selection of Argentine spots and the whole of the electoral programs of the Free Electoral Air-Time (HGPE) (2016-2017) in Brazil. Using qualitative content analysis of the electoral advertising, we argue that the 2011 and 2014 campaigns (in Argentina and Brazil, respectively) display a greater visual hierarchy of the militants in comparison to the previous two campaigns (2007 and 2010). And, for the Brazilian case, we also state that the 2014 campaign introduced a second type of symbolic representation of activism, through references to the trajectory of Dilma as a youth militant during the military dictatorship.

Keywords: activism; electoral campaign; Dilma Rousseff; Cristina Kirchner 


\section{Résumé}

Représentation visuelle et symbolique du militantisme dans les campagnes électorales de Cristina F. de Kirchner (2007 et 2011) et de Dilma Rousseff (2010 et 2014)

Cet article a pour but d'interpréter de manière comparative la place visuellement assignée dans les campagnes électorales de Cristina Fernández de Kirchner (2007 et 2011) et de Dilma Rousseff (2010 et 2014) au militantisme pro-gouvernement en tant que collectif mobilisé et soutien organisé. Ceci, après des campagnes successives qui ont privilégié une image différente: celle du candidat dans un lien direct, et sans médiations, avec la citoyenneté. Le matériel empirique que nous avons collecté consiste en une sélection de spots argentins et la totalité des programmes électoraux de I'HGPE (Horário Gratuito de Propaganda Eleitoral) au Brésil. Sur la base de I'analyse qualitative du contenu de la publicité électorale, nous soutenons que o collectif militant apparaît visuellement plus accentué dans les campagnes de 2011 (Argentine) et 2014 (Brésil) que dans les deux précédentes (2007 et 2010). Et, pour le cas du Brésil, nous suggérons aussi que la campagne de 2014 présente un deuxième mode de représentation du militantisme, par des références à la trajectoire de Dilma en tant que jeune militante pendant la dictature militaire.

Mots-clés: militantisme; campagne électorale; Dilma Rousseff; Cristina Kirchner

Artigo submetido à publicação em 13 de junho de 2017.

Versão final aprovada em 28 de fevereiro de 2018.

Opinião Pública adopta la licencia Creative Commons CC-BY. $(\mathrm{cc}) \mathrm{BY}$ 